\title{
The Language of a Computer-Mediated Communication in Japan: Mobile-Phone E-Mail
}

\author{
Noboru Sakai ${ }^{1}$ \\ ${ }^{1}$ The Center for English as a Lingua Franca, Tamagawa University, Tokyo, Japan \\ Correspondence: Noboru Sakai, The Center for English as a Lingua Franca, Tamagawa University, Tokyo, Japan. \\ Tel: 81-90-1436-5797. E-mail: noboru.sakai@uqconnect.edu.au
}

Received: Mach 22, 2018

doi:10.5539/mas.v12n5p34

\author{
Accepted: April 9, $2018 \quad$ Online Published: April 25, 2018 \\ URL: https://doi.org/10.5539/mas.v12n5p34
}

\begin{abstract}
This study analyzes a Japanese mobile phone e-mail data corpus (created by the researcher) of 43,295 Keitai-mail exchanged for the purpose of personal communication by 60 young people aged 18 to 30 who are familiar with Keitai-mail practices. The result shows that the Keitai-mail analyzed consists on average of approximately 40 moji (symbols) including 3 emoticons per message, showing that composition is short but not overly abrupt - generally Keitai-mail does not finish in the middle of a sentence. Non-standard textual elements, language plays (LP) such as emoticons, long vowel symbols, irregular use of small moji, and non-standard use of each type of script (e.g., use of Katakana instead of Kanji) are found to be governed by the conventions of Standard Japanese and are not totally random occurrences.
\end{abstract}

Keywords: Computer-Mediated Communication (CMC) E-mail, Japanese, orthography

\section{Introduction}

This study investigates the characteristics of language appeared in Japanese mobile phone e-mail (Keitai-mail), as a CMC widely practiced, in order to deepen our understanding how the media influences languages uses in natural or daily communication. To do so, this study prepares a large corpus of raw data of Keitai-mail which has never seen in this quantity, and would be meaningful to analyze this corpus from multiple viewpoints.

Tanaka (2001) notes that when a new type of media emerges, this also gives rise to new expressions and rules of language, and the current rapid improvements in communication technology have indeed led to equally rapid changes in communication style using these media. For example, when SNS are widespread, many investigate the property of SNS. Here very quickly showing the major result. Hård af Segerstad (2005, p. 37) summarises them as the 17 characteristics of language use in SMS, briefly, because of specification and communication mode of SMS, actually language uses were influenced compared with the standard usage.

In Japan, it would be more various patterns of unique language uses because of the larger number of scripts and available picture based symbols. The Japanese language consists of five types of scripts: Hiragana, Katakana, Kanji, Romaji, and Arabic numerals. Hiragana characters are basic Japanese syllables which consist of forty-six characters (e.g., あ，い，う，え，お). Katakana are scripts that are mainly used to spell foreign loan words, with the same sounds as Hiragana (e.g., ア，イ，ウエエ，オ). Kanji are Chinese characters, and since they have been adapted to Japanese usage, Kanji are different from Chinese characters in the Chinese languages in some sense (e.g., Sunday to Saturday in Kanji can be written as 日，月，火，水，木，金，土). Romaji are the alphabet to describe Japanese based on its sound system. Japanese writing also use Arabic numerals. In these five scripts, Hiragana and Katakana are the native Japanese writing systems, whereas the other three share some properties in its shape with language systems from some other countries. Compositions in Japanese writing are the combination of these scripts.

Emoji is pre-installed victure emoticons: for example, most frequently used Emoji in Keitai-mail is a splash of sweat $\left({ }^{\circ}\right)$, shining $\left({ }^{-}\right)$, and a happy face (Sakai, 2013). Similar to Emoji, Japanese Keitai-mail can also use Decome Emoji, which can be downloaded from Internet sites, and can be added to Keitai-mail. In theory, the number of Decome Emoji are unlimited. Moreover, pre-installed symbols in font sets such as $i$ or $\delta$ are inserted as a part of text.

Yamamoto, Ito and Taketsuna (2008) report that the Keitai-mail function is the most often used by university 
students, with phone calls rarely being used. Therefore, Sasahara's (2002) prediction that Keitai-mail is therefore a significant factor in considering the literacy practices of Japanese people. Today, Keitai-mail has become a natural part of language practice which fully reflects users' language practices. This study therefore analyzes authentic Keitai-mail in order to investigate this aspect of the literacy skills of young Japanese people.

\section{Literature Review}

Keitai-mail is a communication medium through which people can express their intention properly only through writing. People cannot depend on non-verbal cues and add extra information when needed. Moreover, the content of Keitai-mail must be clear and concise because the size of the screen is small (Mizuta, Doi, \& Yamamoto, 2004). These restrictions influence language use in Keitai-mail. This section discusses language use and its characteristics in Keitai-mail based on influences from the Keitai interface as well as psychological effects of language use through Keitai-mail. At first glance, Keitai-mail has the following characteristics: 1) speech-like content, 2) rhythmical communication and 3) graphical expressions with emoticons and graphics (Horasawa 2005).

The interface of Keitai influences writing style, even compared with the PC which has a similar function in terms of e-mail (Sasahara, 2002). First of all, Sasaki and Ishikawa (2006) report that many Keitai-mail consists of just one paragraph, and because of the screen size and limited number of letters shown on it, the content is brief and direct because senders want to shorten their original messages to adapt to these restrictions. On this point, Sasaki and Ishikawa (2006) provide evidence that in Keitai-mail, compared to PC e-mail, nouns, adjectives, and verbs are used more than adverbs, particles and conjunctions. This means that paragraphs in Keitai-mail is briefer than in PC e-mail.

In a quantitative study, Kimura (2002) reports on how each type of Japanese script and symbol was used in Keitai-mail using a data corpus of 6011 moji. Table 1 illustrates his results. Based on this result, Kimura argues that a high proportion of Hiragana is a salient characteristic of Keitai-mail (other media include less than $40 \%$ Hiragana, according to a survey by the National Institute for Japanese Language and Linguistics carried out between 1999 and 2001).

Table 1. Use of each type of symbol in Keitai-mail (Kimura, 2002, p.36, slightly modified)

\begin{tabular}{lll}
\hline Type of script & Late teens & Early 20s \\
\hline Hiragana & $59 \%$ & $56 \%$ \\
Katakana & $7 \%$ & $7 \%$ \\
Kanji & $21 \%$ & $22 \%$ \\
Alphabet & $2 \%$ & $1 \%$ \\
Arabic numerals & $2 \%$ & $1 \%$ \\
Symbols & $10 \%$ & $12 \%$ \\
\hline
\end{tabular}

Note. The original study also examined each symbol in newspapers, magazines, and TV. Columns do not sum to $100 \%$ due to rounding.

Generally Keitai-mail consists of short sentences. The use of emoticons supports this tendency in writing Keitai-mail by providing a rich source for expression of emotion or other information (Hayashi, 2007). In addition, instead of using punctuation such as '。' (a full stop), Keitai-mails tend to conclude with emoticons (Nishimura, 2003). More than $90 \%$ of sentences are concluded by emoticons in a study in which Tachikawa (2005) argues that emoticons used at the end of sentences reflect the intention to convey feelings as accurately as possible.

Miyake (2004) demonstrates how a subset of young Japanese women known as Gals play with language in Keitai-mail. Table 2 is an example of Gal language; it shows that they replace Hiragana with other symbols which bear a resemblance in shape to the original Hiragana.

For example, た $(/ \mathrm{ta} /)$ is written with two Katakana ナ and 二 (ナ二). Miyake also mentions that to apply too much creativity increases the difficulty of comprehending texts, but these LP also increase communication opportunities as if users were enjoying a quiz about their meaning within a group of friends. 
Table 2. An example of Gal language based on difficulty of recognition (Miyake, 2004, p.5, slightly modified)

\begin{tabular}{|c|c|}
\hline Difficulty of recognition & Expression \\
\hline Standard & わたしはばかかなとおもう \\
\hline Easy & わたUはは”かかなとおもう \\
\hline Difficult & 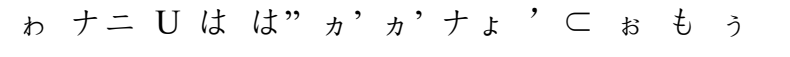 \\
\hline Very difficult & 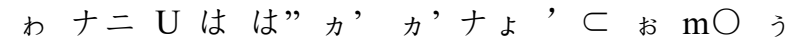 \\
\hline
\end{tabular}

Note. わたしはばかかなとおもう means “I think I am/one is stupid.”

For more on LP, Miyake (2007) summarises non-standard script choices found in Keitai-mail:

1. Kanji instead of Katakana: 怒気怒気ヶドキドキ (ドキドキ, dokidoki’ means 'The sound of a heartbeat', and should be written in Katakana.)

2. Hiragana instead of Katakana: はっぴいたハッピー (ハッピ', happi-’ happy' should be written in Katakana.)

3. Katakana instead of Kanji: リョーカイட了解 (了解, 'ryo ${ }^{-}$kai', 'all right' in Katakana is not conventional writing.)

4. Romaji instead of Hiragana: いい yoていいよ (よ, 'yo', sentence-ending particle, should be written in Hiragana.)

5. English instead of Katakana: Thank you サンキュ (normally written in Katakana.)

6. English acronym instead of Japanese: $\mathrm{NG}$ くダメ(' $\mathrm{NG}$ ' is an acronym for 'no good'.)

Non-standard Letter Choices

1. Small letters 1: ありがとうくありがとう Reducing the size of normal letters.

2. Small letters 2: おやすみいておやすみ Adding a small letter to lengthen the preceding vowel.

3. Long vowel: ...するよこ Lengthening the vowel sound of the preceding letter.

4. Wrong spelling: まぢてまじ，そ掉てそうConsciously taking up a wrong spelling when the pronunciation is unaffected by the mistaken spelling.

5. Additional aspiration mark (Soku-on): よしっヶょし, Expressing a desire to show determination, desperation, etc.

6. Specialised signs: いちゃ(2) いちゃいちゃ Using mathematical, scientific and other specialised signs. In this case, (2)playfully applies the concept of mathematical squaring to avoid having to repeat a whole word.

7. Omitting punctuation:ありがとう命ヶありがとう。Replacing punctuation with graphic characters.

(pp. 64-65, slightly modified)

As for Emoticons, since Keitai-mail includes richer sources of emoticons or special symbols as defaults, people make frequent use of these emoticons and symbols, especially by comparison with their use in other media such as letters, postcards, and PC e-mail (Yamanishi, 2007). In general, people use the emoticons which come already installed in Keitai, but some do create new emoticons from combinations of letters the platform provides. In the latter case, people usually also download new emoticons from Internet sites, or recycle new emoticons received from friends (Ono \& Tokuda, 2005). Because these emoticons and symbols are so easy to use, they often appear in Keitai-mail in order to prevent the text from appearing bland (Yamanishi, 2007).

In addition, young people feel that they can understand the real message of the sender if emoticons are used, since emoticons express intimacy and emotion. Creation of new emoticons is a device to extend this function (Ono \& Tokuda, 2005).

From this point of view, emoticons actually function to convey the emotion of the sender. This is because they substitute for facial expression in Keitai-mail communication (Kato, Kato, Kobayashi, \& Yanagisawa, 2007): people can understand their interlocutors' intentions better when emoticons are used (Takahashi, Fukada, \& Akimitsu, 2005). Therefore they play a role in making communication smoother (Uchida, 2004). As discussed 
previously, people depend heavily on non-verbal cues, particularly facial expressions, in communication in order to understand their interlocutors' intentions and it is very difficult to communicate without such non-verbal cues. Emoticons substitute for these non-verbal cues and therefore they actually support proper understanding of others and smooth communication through Keitai-mail, a written-medium communication. Kawakami (2008) shows how 31 emoticons induce people's reactions, and Ono and Tokuda (2005) discuss 15 emoticons with possible interpretations.

Moreover, since people can visually understand the message when they see emoticons, these symbols can substitute for a word or phrase written using several Japanese syllables (Hayashi, 2007). At the same time, as Ono and Tokuda (2005) point out, although emoticons carry a certain meaning in themselves, people generally interpret their meaning based on the context in which they are used and in the overall e-mail exchange. ${ }^{1}$ Therefore, emoticons are also said to be context-dependent symbols which supportively add an emotion or meaning to content. Emoticon use is an important characteristic of Keitai-mail, so that Keitai-mail without emoticons is sometimes regarded as sloppy (Ono \& Tokuda, 2005) and even induces anger and sadness in interlocutors (Kato et al., 2006b).

One fundamental question relating to emoticons is whether they are pictures or letters. Kimura (2002) investigates this question: her study concludes that people regard emoticons as pictures rather than letters, and that emoticons are used not to replace words written in the five Japanese scripts but to function as supplements or additions. This also can be discussed from the viewpoint suggested by Azuma and Ebner (2008), namely that such emoticons can function as a universal language among speakers of different languages with a certain degree of success. Their report indicates that interpretation of emoticons is not restricted by language and that emoticons therefore can be viewed as not belonging to the scripts of any particular language.

Quantitative data on the difference between Keitai-mail composed by men and women comes from Tochihara (2010), who counts the number of times each script appeared in sample Keitai-mail gained from a role-playing survey. The results show that Keitai-mail written by women consisted of approximately 68 moji, while those written by men had approximately 61. In addition, the proportions of Hiragana, Kanji, and Katakana in the total number of moji used by women and men are $62.6 \%-61.2 \% ; 22.7 \%-24.5 \% ; 3.2 \%-4.2 \%$ respectively. Therefore, men use the basic scripts more than women do. On the other hand, Tochihara's study shows that women use all types of emoticons more than men do, and she also argues that Decome Emoji in particular are seen as being used by women: her findings show that women use them (4.3\%) much more than men $(2.0 \%)$ do.

As the discussion above shows, a dynamic view of Keitai-medium communication, in contrast to studies of different ways of Keitai communication, has yet to be developed. The study of Keitai communication requires theoretical and methodological frameworks that are multidisciplinary in approach such as CMC studies and personal communication studies (Ito, 2005). In addition, Ito and Okabe (2005) point out that Keitai communication research should be approached through its technological, social, practical, and technosocial aspects. This study therefore analyzes Keitai-medium text-based communication from multiple perspectives based on different modes of communication styles. It extends our understanding of how Japanese people, in particular, young people who are the main users of Keitai, create written texts using this mode of communication.

\section{Method}

This study investigates the corpus from raw data of communication practices appeared in Keitai-mail the researchers gained through field work. In detail, this study analyzes 43,295 Keitai-mail for communication purposes collected from 60 Japanese young people (aged 18 to 30, ratio of male to female is 1:1. i.e, 30 male participants and 30 female participants) during May 2009 to January 2010. ${ }^{1}$ The participants use mobile phones sold by the three major Japanese Keitai companies: NTT Docomo, Softbank and au, and the numbers of participants using each Keitai company are as follows: Docomo 28, SoftBank 11, and au 21. Keitai-mail is collected by Keitai-mail backup software Keitai-master $M X$ (ver 4.5) (Jungle Inc., 2009), with selection of participants which Keitai-mail could offer. Because of specification matters, Decome Emoji stored in au mobiles cannot be collected.

\section{Result}

This section examines the overall picture of language use, mostly orthography-related, in the Keitai-mail corpus. For effective presentation of the discussion, this thesis uses the term 'moji' to count other things as well as the five scripts used in writing Japanese (Hiragana, Katakana, Kanji, Romaji [the alphabet], and Arabic numerals). Other symbols such as punctuation and emoticons are also counted as one moji if they occur once in texts. Kaomoji are a combination of pre-set symbols, but since Kaomoji indicate their meaning through this 
combination, one set of Kaomoji is also counted as one moji (e.g., the Kaomoji ' $\mathrm{m}\left(\_\right) \mathrm{m}$ ' can be counted as five moji if we focus only on the number of symbols it contains, but ' $\mathrm{m}\left(\_\right.$) ' indicates the meaning of 'bowing' using these five symbols; this Kaomoji is therefore counted as one moji).

In total, 43,295 Keitai-mail were collected in this study. This number includes 26,403 received Keitai-mail and 16,892 sent Keitai-mail. On average, these Keitai-mail consists of approximately 41.641 moji, made up of 39.024 moji from the five basic scripts and 2.617 emoticons. Figure 1 presents the proportion of Keitai-mail by length.

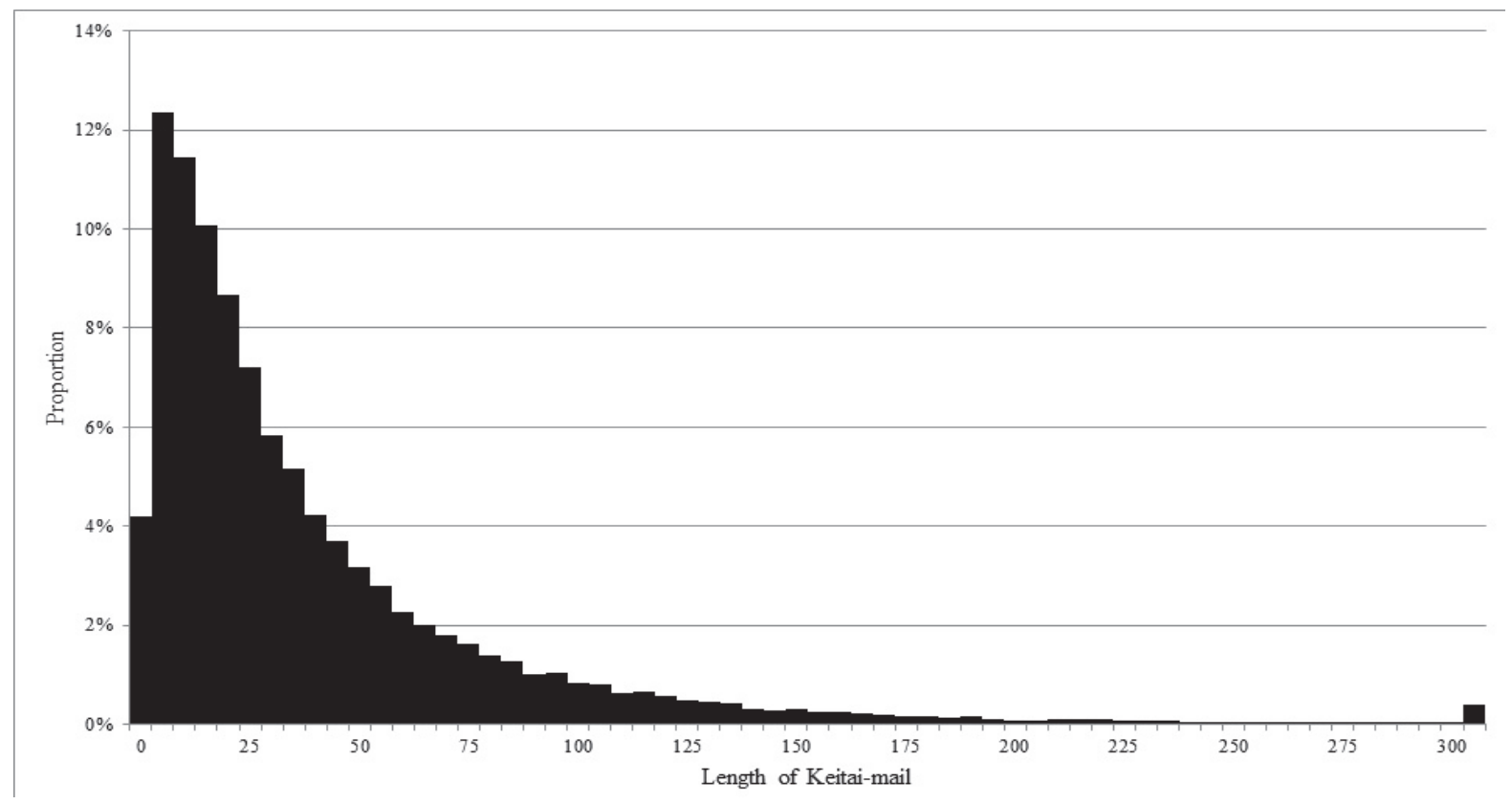

Figure 1. Length of Keitai-mail

Note. Keitai-mail over 300 moji long are grouped together.

With regard to the components of the Keitai-mail, Table 3 summarises how much each script is used. There are 1,801,243 moji in total and Hiragana are included 1,049,492 times, about $59.70 \%$, so Hiragana occur in more than half of the texts. Kanji follows next, and symbols other than the five scripts were found to be the third most frequent component. These non-script symbols include punctuation marks (e.g., '、', '。', parentheses), other pre-installed symbols (e.g., 3 ), and emoticons. The proportion of each type of symbol is similar to that which was reported in 2002 by Kimura, and the use of symbols in Keitai-mail with ten-key input specification is a common tendency of Japanese people from a diachronical perspective.

Table 3. Frequency of occurrence of each type of symbol

\begin{tabular}{llllll}
\hline Type & Frequency & Proportion & Type & Frequency & Proportion \\
\hline Kanji & 379,758 & $21.60 \%$ & Romaji & 2,300 & $0.13 \%$ \\
Hiragana & $1,049,492$ & $59.70 \%$ & Arabic numerals & 7,542 & $0.43 \%$ \\
Katakana & 101,561 & $5.78 \%$ & Etc & 210,279 & $11.96 \%$ \\
Half size Katakana & 7,016 & $0.40 \%$ & Total & $1,801,243$ & \\
\hline
\end{tabular}

To elaborate on the non-script components, Table 4 depicts how many emoticons were found in the corpus in terms of type of emoticon per Keitai-mail message analyzed. This table shows the number of each type of emoticon and its average use. Regarding Emoji and Decome, people use them in two different ways: just as a symbol, as a picture and sometimes as a replacement for words. Broadly speaking, 10\% of these picture icon uses are for replacement purposes. 
Emoticons account for a large proportion (62\%) of the total number of non-script components; this shows that these emoticons have become a fundamental part of Keitai-mail to the extent that their use surpasses that of Katakana, a basic Japanese script.

This section looks at emoticons again, this time focusing on their property of emotional indicator, the primary function of emoticons. Table 5 shows how many of each type of emoticon appear in the Keitai-mail in the data corpus: 114,695 emoticons in 43,296 Keitai-mail.

Table 4. Emoticons in Keitai-mail

\begin{tabular}{lll|lll}
\hline Type & Frequency & $M$ & Type & Frequency & $M$ \\
\hline Emoji as a picture & 87,669 & 2.025 & Decome as a picture & 12,496 & 0.289 \\
Emoji as replacement & 7,627 & 0.176 & Decome as replacement & 1,460 & 0.034 \\
Emoji total & 95,296 & 2.201 & Decome total & 13,956 & 0.322 \\
\cline { 4 - 6 } Kaomoji & 4,044 & 0.093 & Total & 113,296 & 2.617 \\
\hline
\end{tabular}

Table 5. Frequency of emoticons in terms of types

\begin{tabular}{lllll}
\hline Type & Emoji & Kaomoji & Decome $^{*}$ & Total \\
\hline Frequency & 95,381 & 5,342 & 13,972 & 114,695 \\
Proportion & $83.16 \%$ & $4.66 \%$ & $12.18 \%$ & \\
\hline
\end{tabular}

Note. As mentioned in Section 1-4, because of specification matters, Decome on au mobiles cannot be backed up, so the number here is merely an indication.

Each emoticon has two possibilities in terms of its use: replacement of five types of Japanese symbols (i.e., technically, emoticons are used to have interlocutors see these pictures instead of Hiragana/Katakana/Kanji/Romaji/Arabic numerals) or just a simple attachment as a visual icon. In the latter case, emoticons give extra emotional or other information which goes beyond language itself, and the use of emoticons strongly reflects the users' intentions, whether consciously or unconsciously, since they choose to use emoticons as a part of their messages even though emoticons originally do not have a function as language. In other words, emoticons are used as substitutes for body language.

\subsection{Emoji}

Of the three major types of emoticons in Japanese Keitai-mail, Emoji, or pre-installed picture symbols, account for a very large proportion of total emoticon use: more than $80 \%$. Therefore, they are a major source of emotional indicators used in Keitai-mail

Table 6 exhibits how many Emoji are used from each Keitai carrier: Docomo, SoftBank, and au. The table firstly shows the total number of occurrences of Emoji for each carrier. For example, 36,431 Emoji are from Docomo. In addition, Table 6 also shows the Emoji most used by showing the occurrences of each Emoji and its proportion in the total occurrences for each company. For instance, II is the fifth most used in Keitai-mail from Docomo phones: it appears 1,728 times, accounting for 4.743\% of total Emoji occurrences from Docomo.

Across the three carriers, even though they have different sets of Emoji installed. users employ Emoji in a similar fashion. The top three are Emoji showing a splash of sweat ( $\left.{ }^{\circ}\right)$, shining $\left({ }_{*}^{*}\right)$, and a happy face (B). (Note 4). The first expresses a feeling of panic; the second indicates something good; the last represents the emotion of happiness. After these three, a question mark (? $)$, double exclamation mark (??) and a combination of question and exclamation marks (??) are often used. The frequent use of these emoticons can be attributed to the frequency of these forms of punctuation in general, but an interesting point here is that double exclamation marks are much preferred to a single exclamation mark ( ) when double exclamation marks are available. This is evidence of Emoji's function as an emotional indicator since users choose Emoji to represent their feelings, here how very surprised they are. Other Emoji used frequently (ranking in the top 10) are: music notes $\left(\mathcal{D}^{\mathcal{P}}\right.$ ), a heart mark $(\$)$, an upward arrow $(\hat{\xi})$ and other types of happy faces $(\Theta)$. The Emoji shown above indicate that users use Emoji which (in relative terms) represent some form of happiness or goodness, in addition to punctuation marks. 
Table 6. The total number and top 30 Emoji in Keitai-mail

\begin{tabular}{|c|c|c|c|c|c|c|c|c|c|}
\hline & \multicolumn{3}{|c|}{ Docomo } & \multicolumn{3}{|c|}{ SoftBank } & \multicolumn{3}{|l|}{$\mathrm{au}$} \\
\hline & 364 & & & 130 & & & 459 & & \\
\hline 1 & 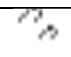 & 2654 & $7.285 \%$ & 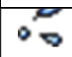 & 1175 & $9.027 \%$ & B) & 3378 & $7.354 \%$ \\
\hline 2 & $\Rightarrow$ & 2539 & $6.969 \%$ & & 1021 & $7.844 \%$ & $\hat{n}$ & 3133 & $6.821 \%$ \\
\hline 3 & 8 & 2387 & $6.552 \%$ & (9) & 676 & $5.194 \%$ & $s+$ & 3061 & $6.664 \%$ \\
\hline 4 & !! & 1728 & $4.743 \%$ & 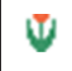 & 510 & $3.918 \%$ & 7 & 2444 & $5.321 \%$ \\
\hline 5 & $S$ & 1717 & $4.713 \%$ & $\Omega$ & 483 & $3.711 \%$ & !! & 2277 & $4.957 \%$ \\
\hline 6 & 7 & 1711 & $4.697 \%$ & $\approx$ & 414 & $3.181 \%$ & $d$ & 2097 & $4.565 \%$ \\
\hline 7 & 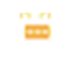 & 1568 & $4.304 \%$ & "y & 395 & $3.035 \%$ & $?$ & 1897 & $4.130 \%$ \\
\hline 8 & 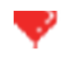 & 1303 & $3.577 \%$ & $v$ & 380 & $2.919 \%$ & $J$ & 1802 & $3.923 \%$ \\
\hline 9 & $J$ & 1236 & $3.393 \%$ & $\theta$ & 361 & $2.774 \%$ & 6 & 1762 & $3.836 \%$ \\
\hline 10 & 7 & 1033 & $2.835 \%$ & $\equiv$ & 349 & $2.681 \%$ & "E & 1212 & $2.639 \%$ \\
\hline 11 & 疋 & 929 & $2.550 \%$ & $\stackrel{\prime \prime \prime \prime}{ }$ & 346 & $2.658 \%$ & $\sigma$ & 1122 & $2.443 \%$ \\
\hline 12 & {$[7$} & 817 & $2.243 \%$ & $?$ & 337 & $2.589 \%$ & : & 1046 & $2.277 \%$ \\
\hline 13 & 增 & 787 & $2.160 \%$ & 28 & 322 & $2.474 \%$ & 㲅 & 977 & $2.127 \%$ \\
\hline 14 & 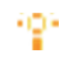 & 778 & $2.136 \%$ & $\approx$ & 302 & $2.320 \%$ & $\equiv 3$ & 865 & $1.883 \%$ \\
\hline 15 & 1017 & 773 & $2.122 \%$ & 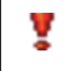 & 282 & $2.167 \%$ & $\nabla$ & 747 & $1.626 \%$ \\
\hline 16 & $=3$ & 766 & $2.103 \%$ & $\Theta$ & 258 & $1.982 \%$ & $\nabla^{\prime \prime}$ & 738 & $1.607 \%$ \\
\hline 17 & 7 & 738 & $2.026 \%$ & $\hat{\theta}$ & 247 & $1.898 \%$ & (5) & 680 & $1.480 \%$ \\
\hline 18 & $\%$ & 693 & $1.902 \%$ & $\dot{\theta}$ & 245 & $1.882 \%$ & (5) & 622 & $1.354 \%$ \\
\hline 19 & 30 & 620 & $1.702 \%$ & $\Theta$ & 229 & $1.759 \%$ & (5) & 589 & $1.282 \%$ \\
\hline 20 & ") & 595 & $1.633 \%$ & $\varphi$ & 226 & $1.736 \%$ & 3 & 584 & $1.271 \%$ \\
\hline 21 & $v$ & 587 & $1.611 \%$ & in & 218 & $1.675 \%$ & 8 & 571 & $1.243 \%$ \\
\hline 22 & 3 & 570 & $1.565 \%$ & $\mathscr{B}$ & 214 & $1.644 \%$ & 0 & 568 & $1.237 \%$ \\
\hline 23 & + & 523 & $1.436 \%$ & 目 & 212 & $1.629 \%$ & 8 & 553 & $1.204 \%$ \\
\hline 24 & $y^{\prime \prime}$ & 506 & $1.389 \%$ & $\mathscr{B}$ & 200 & $1.537 \%$ & 7 & 538 & $1.171 \%$ \\
\hline 25 & $\%$ & 501 & $1.375 \%$ & $\fallingdotseq \overline{0}$ & 181 & $1.391 \%$ & 6 & 523 & $1.139 \%$ \\
\hline 26 & $\nabla$ & 489 & $1.342 \%$ & $\because$ & 172 & $1.321 \%$ & $\theta$ & 481 & $1.047 \%$ \\
\hline 27 & ! & 467 & $1.282 \%$ & 蛅 & 165 & $1.268 \%$ & 刑 & 464 & $1.010 \%$ \\
\hline 28 & 8 & 426 & $1.169 \%$ & ) & 149 & $1.145 \%$ & 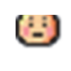 & 393 & $0.856 \%$ \\
\hline 29 & $*$ & 381 & $1.046 \%$ & 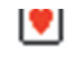 & 136 & $1.045 \%$ & 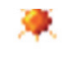 & 389 & $0.847 \%$ \\
\hline 30 & $\theta$ & 323 & $0.887 \%$ & $B \theta$ & 127 & $0.976 \%$ & 5 & 361 & $0.786 \%$ \\
\hline
\end{tabular}

After that in the ranking come Emoji showing sadness or something bad, such as an unhappy face $(\Varangle)$ or a downward arrow ( 7 ), yet we also find further Emoji which indicate rejoicing of some kind, so that this tendency is continued. Therefore, it can be said that the most widespread application of Emoji by users is to 
describe positive aspects of feeling. Other types of Emoji found in the ranking are information about a sunny day

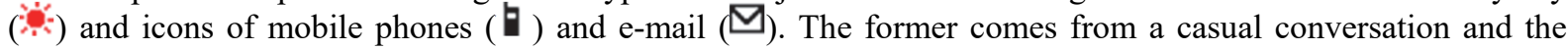
latter are used to ask someone to call or e-mail them. Therefore, it is natural that people add these Emoji as a part of Keitai-mail texts. The present study goes beyond the ranking of frequently used emoticons by Yasuhara et al. (2009) in that its data show that abstract Emoji are displayed more often than Emoji indicating more concrete meanings. However, both studies show similar sets of emoticon uses on the whole and this is supporting evidence that people use the same set of emoticons in their text composition.

In Table 6, several types of Emoji which carry different extralinguistic information are shown. At the same time, however, the Emoji frequently used are actually quite limited. The tables shows that the first three exhibit a high proportion, and then the slopes decrease sharply until rank 10; after that the proportion is moderately decreased. This means that there are great differences in the occurrences of each Emoji. In particular, most Emoji are rarely or not used: the right side of Figure 2 shows that Emoji ranked below 50 are very few in number (actually less than $1 \%$ ) and soon reach almost 0 .

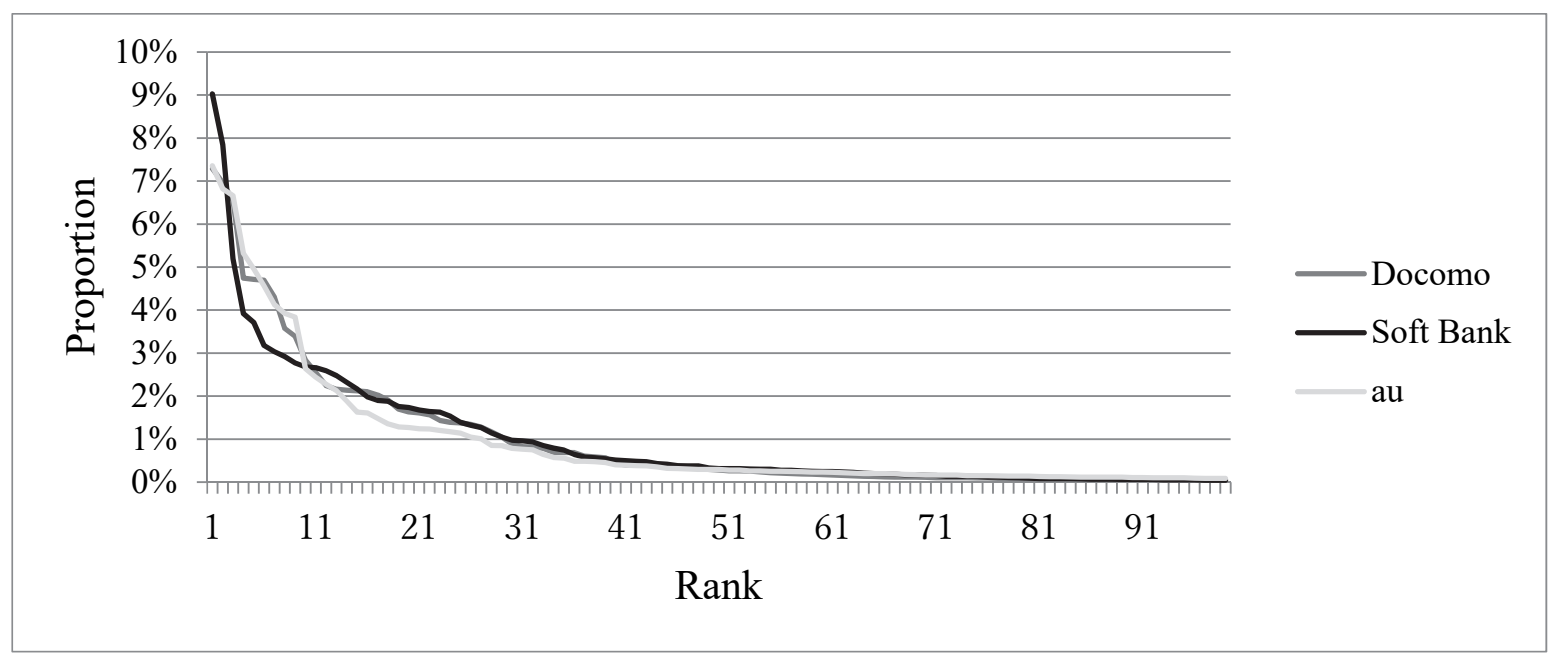

Figure 2. The proportion of each Emoji use (Top 100)

To sum up, Emoji use has several characteristics:

- Emoji with positive meanings are much more often used than those with negative meanings

- Emoji punctuation marks are also used often

- People use several particular Emoji frequently and many other Emoji do not show much uptake

\subsection{Kaomoji}

There are 5,342 Kaomoji in 605 patterns in the data corpus. Table 7 shows the top 20 Kaomoji: other than the first four, each pattern only occurs less than $2 \%$, with Kaomoji ranked below 18 th at less than $1 \%$. In addition, when we look at the Kaomoji ranked 2nd and 3rd, or 5th and 6th, there are only very slight differences between them: the two are the almost same. Therefore, the Kaomoji most often used are very limited in number - small variations with a minor change in pattern.

As with the Emoji tendency shown previously, Kaomoji representing happiness are used very often in Keitai-mail. A particular characteristic here is that users often employ a Kaomoji showing a 'bow' $\left(\mathrm{m}\left(\_\right) \mathrm{m}\right)$, which accounts for around $20 \%$ of Kaomoji use. The reason for the high frequency of occurrence of this one is that bowing is expected when asking for something or showing appreciation, and users express this in their Keitai-mail. At the same time, Emoji do not have an icon which can represent this as effectively as Kaomoji, so the use of this Kaomoji $\left(\mathrm{m}\left(\_\right) \mathrm{m}\right)$ naturally increases, for cultural and technical reasons.

Another interesting aspect is that one Kaomoji $(><)$ is used often, but its interpretation is not straightforward. Some interpret this as a representation of happiness while others see it as a reflection of sadness (crying). The context of the message usually enables users to interpret this as the sender intends, but sometimes miscommunication occurs since this Kaomoji has two opposite interpretational possibilities. In other words, it 
may happen that use of Kaomoji transmits unintended emotional messages, and this can cause confusion when the possible interpretation of a particular Kaomoji is not suitable to the given setting.

\subsection{Decome}

Because the system does not enable users to backup au mobiles' Decome, I will here discuss Decome only briefly. There are 13,972 Decome in the Keitai-mail from Docomo and SoftBank mobile phones. Decome function mainly as a replacement for Emoji: the difference is only between pre-installed or downloaded. Compared to 47,206 occurrences of Emoji in Keitai-mail from Docomo and SoftBank, the number of Decome is approximately $30 \%$ of that. Therefore, Decome is still more optional and not as popular as Emoji so far. This can be attributed to the extra burden in using them and to the fact that sufficient Emoji are provided for expressing emotion in general use.

Table 7. Top 20 Kaomoji in Keitai-mail

\begin{tabular}{|c|c|c|c|}
\hline Rank & Kaomoji & Frequency & Proportion \\
\hline 1 & $(* *)$ & 616 & $11.53 \%$ \\
\hline 2 & $\mathrm{~m}\left(\_\_\right) \mathrm{m}$ & 544 & $10.18 \%$ \\
\hline 3 & $\mathrm{~m}\left(\_\right) \mathrm{m}$ & 483 & $9.04 \%$ \\
\hline 4 & $\left(>\_<\right)$ & 344 & $6.44 \%$ \\
\hline 5 & $(* \wedge \wedge *)$ & 100 & $1.87 \%$ \\
\hline 6 & $\left(* \wedge_{-} \wedge *\right)$ & 91 & $1.70 \%$ \\
\hline 7 & $\left(\wedge_{-} \wedge *\right) /$ & 89 & $1.67 \%$ \\
\hline 8 & $\left({ }^{\wedge}--^{\wedge}\right) /$ & 86 & $1.61 \%$ \\
\hline 9 & $\left(* \wedge 0^{\wedge *}\right)$ & 71 & $1.33 \%$ \\
\hline 10 & $\left({ }^{\wedge} \mathrm{O}^{\wedge}\right) /$ & 71 & $1.33 \%$ \\
\hline 11 & $\wedge \wedge *$ & 68 & $1.27 \%$ \\
\hline 12 & $\left(\wedge^{\wedge}-^{\wedge}\right)$ & 64 & $1.20 \%$ \\
\hline 13 & $\wedge \wedge$ & 60 & $1.12 \%$ \\
\hline 14 & $\left(\forall^{\prime} \forall{ }^{\prime}\right)$ & 59 & $1.10 \%$ \\
\hline 15 & $\left({ }^{\wedge} \mathrm{O}^{\wedge}\right)$ & 57 & $1.07 \%$ \\
\hline 16 & $\left(\mathrm{~T}_{-} \mathrm{T}\right)$ & 56 & $1.05 \%$ \\
\hline 17 & $\left({ }^{\prime} \cdot \omega \cdot{ }^{\prime}\right)$ & 55 & $1.03 \%$ \\
\hline 18 & $\left(* \wedge \_*\right)$ & 53 & $0.99 \%$ \\
\hline 19 & $\left(*^{\prime}\right.$ д $\left.{ }^{\prime *}\right)$ & 46 & $0.86 \%$ \\
\hline 20 & $\left.\mathrm{o}^{(\wedge-\wedge}\right) \mathrm{O}$ & 43 & $0.80 \%$ \\
\hline
\end{tabular}

\subsection{Kanji in Keitai-mail}

In the whole corpus, there are 2,156 different Kanji in a total of 314,148 occurrences. The number here excludes Kanji used in proper names (e.g., names of places, shops) and related usage in order to analyze what Kanji are used for general communication purposes. Table 8 shows the top 50 Kanji appearing in the corpus. It shows that 日 was the most used, accounting for about $3.9 \%$ of Kanji use. The top 10 Kanji each account for over $1 \%$ of total Kanji use, while 2,147 Kanji appear less frequently than to account for $1 \%$.

In some cases, several of the most frequently used Kanji combine in one word such as 4,208 occurrences of 今日 ('today'), 3,218 occurrences of 明日('tomorrow'), 2,649 occurrences of 連絡 ('reporting'), and 2,334 
occurrences of 大丈夫 ('OK'). The Kanji in Table 3 can usually be found in Japanese writing used alone (e.g., 3,216 occurrences of 今) or with a certain Hiragana (okurigana: for example, in 4,768 occurrences of 行 $</ \mathrm{i} \mathrm{ku} /$, $<$ is an okurigana), but some Kanji are found in compound words containing two or more Kanji as shown above. This boosts the number of Kanji appearing, even though some Kanji are not used so often with their original meaning, such as 夫 (ranked 18), of which the original meaning is 'husband' but which today is mainly used as a part of 大丈夫.

In terms of proportion, the top 50 Kanji account for $42.2 \%$ of total Kanji use; the top 100 Kanji (the Kanji ranked 100 are 加 (add) and 結 (tie), 718 occurrences each), for 57.8\%; and the top 300 Kanji for $81.7 \%$ (要 (need) is the 300th Kanji, 208 occurrences). This shows that even though there are over 2,000 Kanji used in the Keitai-mail, only a limited number are used frequently.

Table 8. Top 50 Kanji

\begin{tabular}{|c|c|c|c|c|c|c|c|c|c|c|}
\hline Rank & Kanji & Meaning & $\mathrm{F}$ & $P$ & Rank & Kanji & Meaning & & $\mathrm{F}$ & $P$ \\
\hline 1 & 日 & $\begin{array}{l}\text { Day/ } \\
\text { Sunday }\end{array}$ & 12,051 & 3.858 & 26 & 楽 & Enjoy & & 2,014 & 0.645 \\
\hline 2 & 今 & Now & 9,353 & 2.994 & 27 & 本 & Book & & 1,943 & 0.622 \\
\hline 3 & 行 & Go & 6,655 & 2.131 & 28 & 張 & Tension & & 1,910 & 0.612 \\
\hline 4 & 大 & Big & 4,161 & 1.332 & 29 & 人 & Human & & 1,893 & 0.606 \\
\hline 5 & 思 & Think & 3,763 & 1.205 & 30 & 遅 & Delay & & 1,891 & 0.605 \\
\hline 6 & 明 & Light & 3,728 & 1.194 & 31 & 分 & Minute & & 1,886 & 0.604 \\
\hline 7 & 会 & Meet & 3,300 & 1.057 & 32 & 前 & $\begin{array}{l}\text { Forward/ } \\
\text { Before }\end{array}$ & & 1,880 & 0.602 \\
\hline 8 & 気 & Feel & 3,278 & 1.049 & 33 & 疲 & Tired & & 1,864 & 0.597 \\
\hline 9 & 事 & Matter & 3,175 & 1.017 & 34 & 見 & See & & 1,850 & 0.592 \\
\hline 10 & 話 & Talk & 3,123 & 1.000 & 35 & 月 & $\begin{array}{l}\text { Monday/ } \\
\text { Moon }\end{array}$ & & 1,840 & 0.589 \\
\hline 11 & 連 & Connect & 2,872 & 0.920 & 36 & 曜 & $\begin{array}{l}\text { Days of } \\
\text { week }\end{array}$ & $\mathrm{a}$ & 1,758 & 0.563 \\
\hline 12 & 来 & Come & 2,836 & 0.908 & 37 & 入 & Enter & & 1,757 & 0.563 \\
\hline 13 & 出 & Out & 2,818 & 0.902 & 38 & 頑 & Try & & 1,738 & 0.556 \\
\hline 14 & 絡 & Connect & 2,684 & 0.859 & 39 & 電 & Electricity & & 1,651 & 0.529 \\
\hline 15 & 帰 & Go back & 2,617 & 0.838 & 40 & 学 & Study & & 1,632 & 0.523 \\
\hline 16 & 合 & Fit & 2,583 & 0.827 & 41 & 生 & Live & & 1,620 & 0.519 \\
\hline 17 & 時 & Time & 2,478 & 0.793 & 42 & 良 & Good & & 1,559 & 0.499 \\
\hline 18 & 夫 & Husband & 2,364 & 0.757 & 43 & 当 & Hit & & 1,540 & 0.493 \\
\hline 19 & 願 & Hope & 2,357 & 0.755 & 44 & 变 & Change & & 1,521 & 0.487 \\
\hline 20 & 丈 & Length & 2,345 & 0.751 & 45 & 着 & Arrive & & 1,499 & 0.480 \\
\hline 21 & 間 & Between & 2,258 & 0.723 & 46 & 終 & Finish & & 1,495 & 0.479 \\
\hline 22 & 解 & Understand & 2,156 & 0.690 & 47 & 定 & Confirm & & 1,455 & 0.466 \\
\hline 23 & 一 & One & 2,143 & 0.686 & 48 & 仕 & Work & & 1,440 & 0.461 \\
\hline 24 & 言 & Comment & 2,132 & 0.683 & 48 & 夜 & Night & & 1,440 & 0.461 \\
\hline 25 & 了 & Finish & 2,093 & 0.670 & 50 & 予 & Prepare & & 1,392 & 0.446 \\
\hline
\end{tabular}

Abbreviations. F: Frequency, P: Proportion 
In addition, most Kanji are from the Kaitei Jōyō Kanjihyō (Revised List of Characters for General Use). 1,863 of the 2,156 different Kanji are from this list, i.e., $86.4 \%$ of the total number of different Kanji. In particular, 312,343 occurrences of Jōyō Kanji account for $99.4 \%$ of all Kanji occurrences. This is because the Kanji on the Revised List are the Kanji which are considered essential for writing Japanese. The total number of characters on the Revised List is 2,136; 87.2\% of them are included in Keitai-mail in some way.

As for Kanji which are not part of the Revised List, Table 9 shows the top 5 most frequently used non-Jōyō Kanji. 嬉 occurs 416 times in the whole corpus, ranking 170th among all Kanji occurrences. Table 9 shows that 逢 appears only 38 times even though this is the fifth most frequent non-Jōyō Kanji in Keitai-mail, and Kanji outside the Jōyō Kanji list are rarely used. However, 嬉, and even 貫, are often used. They are in the top 25\% of high frequency Kanji. Therefore, these Kanji are very common.

Table 9. Top 5 non-Jōyō Kanji

\begin{tabular}{llll}
\hline Rank in total & Kanji & Meaning & Frequency \\
\hline 170 & 嬉 & Happy & 416 \\
421 & 鿓 & Receiving gifts & 127 \\
634 & 繋 & Connect & 61 \\
645 & 綺 & Beautiful & 57 \\
772 & 逢 & Meet & 38 \\
\hline
\end{tabular}

On the other hand, even though the revised Jōyō Kanji list contains 2,136 Kanji, 273 (12.8\%) of these are not used in Keitai-mail as part of common daily literacy practice. At the same time, $152 \mathrm{Kanji}$ are only found once in the corpus and 99 other Kanji appear only twice in these Keitai-mail exchanges. This indicates that Keitai-mail practices, or similar electronic-based written com

To sum up, since Kanji can be used both as single moji and in compound with other Kanji, the frequency ranking of each Kanji may not be what one might expect when considering only the meaning of the Kanji when it occurs alone (e.g., 夫, 了). However, almost all Kanji occurrences come from the revised Jōyō Kanji list, and they can certainly be seen frequently in daily communication. At the same time, a few non-Jōyō Kanji like 嬉 occur often in the corpus, and many Jōyō Kanji are used either very rarely or not at all.

\subsection{Emoji as Replacements}

The language of Keitai-mail texts departs from the normal conventions of written Japanese in its use of emoticons for replacement purposes. Emoticons are a major component of Keitai-mail. Some of them are used to decorate texts to add extra visual effect, in most cases an exhibition of writers' state of emotion and/or a reflection of their underlying motivation as to how they would like to treat the atmosphere of exchanges and/or interlocutors. Others are used to replace parts of the text: either they are simply substituted for one of the five basic scripts and pre-installed basic symbols such as punctuation marks, or the meaning of the picture indicates that a symbol such as $\square$ is a replacement for the whole word 'e-mail'. Both Emoji and Decome can be used for this purpose. This section discusses Emoji since they are pre-installed (i.e., the number is restricted) and therefore will exhibit a certain consistency in their use compared to Decome, which in theory have limitless applications.

There are a total of 7,627 Emoji in the corpus which were used for this purpose of replacement. The replaced Emoji which play an essential part in composition and cannot be omitted to make sense of the texts are counted. For example, where there are two or more Emoji displaying question marks at the end of a sentence, only the first one is counted as an Emoji used as a replacement and the others are treated as just an extra decoration because the meaning of the sentence is clear without them. Table 10 summarises which Emoji were substituted for the five types of script and other pre-installed symbols.

Table 10 shows the types of script that tend to be replaced. The first group is question marks (e.g., "W or !?). The second is Arabic numerals: however, this does not mean Emoji for all ten Arabic numerals are used at a similar rate, as the frequency and occurrences are context-dependent. The third is Emoji that are similar in appearance to long vowel symbols: $m$ and $\sigma$. The fourth is an OK symbol: $\overline{0 K}$, and a symbols are mainly replaced by emoticons; this is a major method used to embellish Keitai-mail in a simple way. 
Table 10. Incorporation frequency of Emoji for replacement

Docomo

\begin{tabular}{|c|c|c|c|c|c|c|c|c|c|c|c|c|c|c|c|c|c|c|c|}
\hline !? & 1657 & 日 & 59 & 7 & 31 & [4] & 13 & a: & 5 & 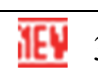 & 3 & 零 & 2 & 슴 & 2 & 四 & 1 & 约 & 1 \\
\hline$\overline{\underline{a K}}$ & 139 & 员 & 54 & $\Delta$ & 30 & 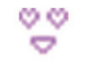 & 13 & 舟 & 5 & 피 & 3 & $\therefore$ & 2 & 8 & 2 & $f^{\text {flit }}$ & 1 & $\check{\gamma}$ & \\
\hline 2 & 137 & $\Rightarrow \mathbf{9}$ & 47 & $m$ & 27 & 6 & 11 & 윾 & 4 & 222 & 3 & $\searrow$ & 2 & $\infty$ & 1 & $\underline{\underline{p_{\varepsilon}}}$ & 1 & $\underline{\underline{G G}}$ & 1 \\
\hline$\nabla$ & 127 & "今心 & 47 & 闻 & 27 & 实 & 9 & (P) & 4 & 0 & 3 & $\sqrt{6}$ & 2 & II & 1 & $\therefore$ & 1 & 38 & 1 \\
\hline 1 & 95 & 监 & 44 & 9 & 23 & 园 & 8 & 훙 & 4 & 믕 & 3 & (1) & 2 & 8 & 1 & 8 & 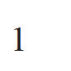 & (2) & 1 \\
\hline 6 & 90 & 5 & 43 & 可 & 20 & 早 & 6 & 4 & 3 & . & 2 & (C) & 2 & îi & 1 & 8 & & & \\
\hline$\gamma$ & 86 & 可 & 32 & (0) & 20 & $=$ & 6 & ry & 3 & $\oplus$ & 2 & 空 & 2 & 3 & 1 & 6 & 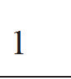 & & \\
\hline \\
\hline & 2374 & $\nabla$ & 28 & 䱇 & 6 & ()) & 4 & 8 & 3 & 面 & 2 & $\infty$ & 1 & ब्यु & 1 & New & 1 & 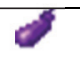 & 1 \\
\hline ?? & 686 & 1 & 23 & 皿 & 5 & 煘 & 4 & $\mathbf{0}$ & 3 & 80 & 2 & $\Psi$ & 1 & 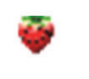 & 1 & $8^{\mathrm{III}}$ & II ${ }_{1}$ & (6) & 1 \\
\hline$\sigma$ & 101 & 国 & 23 & 四 & 5 & 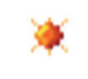 & 3 & 回 & 3 & |Uి? & 2 & (1) & 1 & $\Rightarrow$ & 1 & $0^{I V}$ & $v_{1}$ & in & 1 \\
\hline 霄 & 96 & 2 & 15 & $\Psi \|$ & 5 & $\theta$ & 3 & 2 & 3 & $\Leftrightarrow$ & 2 & $y$ & 1 & $x$ & 1 & 画 & 1 & $\nabla_{6}$ & \\
\hline$\Xi$ & 87 & 焉 & 13 & $\theta$ & 5 & $\%$ & 3 & 0 & 3 & 圆 & 2 & 翸 & 1 & $\Leftrightarrow$ & 1 & 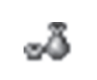 & 1 & $g$ & 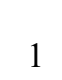 \\
\hline$\theta$ & 64 & 要 & 11 & $\Theta$ & 5 & $-k$ & 3 & $\theta$ & 3 & 目范 & 2 & A & 1 & $\left(8^{I I}\right.$ & 1 & 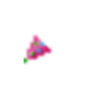 & 1 & 7 & 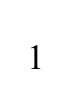 \\
\hline 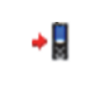 & 59 & $0 \mathrm{~B}$ & 11 & ㄹ & 4 & 3 & 3 & 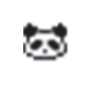 & 3 & $\infty$ & 2 & 재파 & 1 & 逍 & 1 & 口 & 1 & $\omega$ & 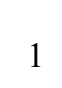 \\
\hline 白 & 50 & $\theta$ & 7 & ลิ & 4 & 5 & 3 & 国 & 2 & $8^{\mathrm{I}}$ & 2 & एक & 1 & $\equiv 3$ & 1 & $\sqrt{b}$ & 1 & $\leftrightarrow$ & 1 \\
\hline 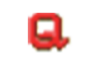 & 47 & 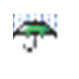 & 6 & $\theta$ & 4 & 7 & 3 & 8 & 2 & 영 & 2 & s. & 1 & 00 & 1 & 0 & 1 & 器 & 1 \\
\hline$\rightarrow \square$ & 43 & 圆 & 6 & $\theta$ & 4 & 9 & 3 & 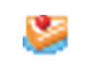 & 2 & 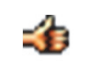 & 2 & $\varphi_{0}$ & 1 & 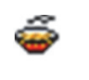 & 1 & $\Leftrightarrow$ & 1 & 4 & 1 \\
\hline$\rightarrow$ & 35 & 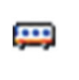 & 6 & $\theta$ & 4 & 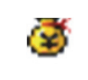 & 1 & & & & & & & & & & & & \\
\hline
\end{tabular}

Note. I. Face in failure; II. Happy face; III. Face with heart-shaped-eyes; IV. Embarrassing

SoftBank

\begin{tabular}{|c|c|c|c|c|c|c|c|c|c|c|}
\hline $\mathscr{V}$ & 370 & 슙 7 & & $\$ 2$ & 5 2 & 是 1 & $\Leftrightarrow 1$ & 1 & प1 1 & $z^{2}$ \\
\hline ? & 208 & 固 5 & $00_{3}$ & $\theta_{2}$ & & 䂹 1 & 1 & 11 & 粗 1 & $\bar{\epsilon}_{3} \approx \bar{\psi}$ \\
\hline$\square$ & 31 & $\Theta_{4}$ & 剀 2 & $\nabla_{2}$ & $8_{1}$ & $\mathrm{YH}_{1}$ & $S_{1}$ & $7)_{1}$ & $0_{1}$ & 5 \\
\hline$A$ & 9 & 䌿 3 & $\mathbb{B P}_{2}$ & 2] 2 & 首 & $\theta$ & $\Leftrightarrow$ & [1 1 & 믄 1 & 9 \\
\hline
\end{tabular}

Other groups of Emoji are replacements made on the basis of their intended meanings. One major group of this type is Emoji relating to Keitai and Keitai-mail communication, such as $\boldsymbol{\nabla}$ and $\mathbf{b}$. Communication via Keitai (as a telephone) and Keitai-mail is very common and so people use these emoticons as replacements for words which use several moji (e.g., メール [mail] consists of three moji); this is natural in order to increase the effectiveness of input for such a frequent part of communication. Emoji indicating transportation (e.g., $\Rightarrow$ or 只) and accommodations (e.g., $\boldsymbol{*}$ and $\mathbf{m}^{\mathrm{n}}$ ) are also used frequently in Keitai-mail. Keitai-mail used as a daily communication device increase the use of these Emoji since they commonly include topics such as commuting and major places of activity. In both cases, Emoji are effectively used in the input method and for purposes of decoration in Keitai-mail, and the proportion of approximately $8 \%$ of Keitai-mail which feature Emoji as replacements shows the effectiveness of Emoji application. 


\subsection{Kanji replaced by Hiragana}

This section introduces details of how young informants choose to use Hiragana in place of Kanji in Keitai-mail, showing the number of words in the data corpus where Hiragana are used where Kanji would normally be expected based on the guideline of Kanji use in formal writing from The Agency for Cultural Affairs (Bunkach $\overline{0})(2010)$.

17,801 words are converted to Hiragana from 749 Kanji (several Kanji are converted into Hiragana with different pronunciations based on their usage and combinations with other Kanji). However, Table 11 shows that Kanji are not always replaced with yomigana, or pronunciation-based Hiragana; some LP are applied when people use Hiragana as an alternative to Kanji. Several LP patterns were found in the collected Keitai-data.

Firstly, some large Hiragana moji are replaced by small Hiragana moji. The example in Table 11 shows that $了$ 解 is normally written as りょうかい in yomigana. Some people, however, write it as りょうかい in Keitai-mail, where this version of りょうかい contains two small Hiragana, う and い(りょ之から). The table shows that this kind of replacement occurs in 136 cases. In 237 cases, long-vowel symbols are used in place of a vowel. In this example, $j$ is replaced by the long vowel symbol '- '. In another 337 cases, the long vowel is replaced with another syllable: in りょつかい, う is replaced by つ, which is not allowed under orthography rules. Addition and omission of some syllables/components are also seen.りょかい omits the う which should be in the middle, and りょうか〜い adds an extra long vowel symbol ' $~$ ' in the middle. A small number of conversions apply capitalisation of some parts of yomigana writing: りょうかい has a capital instead of a small $ょ$. Other than these patterns, 98 cases contain more than two LP in Hiragana formation. The details of each pattern are discussed later in this section.

Table 11. Frequency of Kanji written in Hiragana and language play

\begin{tabular}{|c|c|c|}
\hline Pattern & Frequency & Example:了解 \\
\hline Just as yomigana & 16,388 & りょうかい \\
\hline Small moji & 136 & りょ之か心 \\
\hline Long vowel symbols & 237 & りょ二かい \\
\hline Replacement in syllables & 337 & りょつかい \\
\hline Omission of components & 490 & りょ_かい \\
\hline Additional components & 109 & りょうか〜い \\
\hline Capitalisations & 6 & りょうかい \\
\hline Combination/other patterns & 98 & りょ二か二い \\
\hline Total & 17,801 & \\
\hline
\end{tabular}

Note. The underlined parts are the places where language plays are applied.

Table 11 also shows that the application of LP is less than $8 \%$ in total, so LP are not a major factor in people's use of Hiragana instead of Kanji. At the same time, however, we also see the phenomenon that LP do, even if only slightly, influence the Hiragana used in place of Kanji.

Table 12 shows the top 50 words in which Hiragana have been used instead of Kanji. In this table, the same word with different pronunciations is treated separately since a difference in pronunciation can differentiate the meaning of Kanji in many places (even though only slightly).

Table 12 also shows the numbers of Hiragana patterns. The table includes information on how many times each Kanji is converted into Hiragana, and gives a ranking based on that. For example, 了解 (which is shown as the example in Table 12) ranks 23rd with 211 conversions.

In addition, how many LP categories are used is also illustrated. For instance, 182 examples of 了解 apply some kind of LP, and they encompass 5 categories of LP out of the 7 shown in table $6.62^{2}$ The 182 patterns make this rank 2, the second largest group of Hiragana usage with LP (Table 6.7 shows 本当 is the 1st (320 patterns) and 了解 is the 2 nd (182 patterns)).

In general, commonly used words appear on the table with high frequency, and because of this commonality, these Kanji are naturally converted into Hiragana. 
Table 12. Top 50 frequent Hiragana conversions from Kanji

\begin{tabular}{|c|c|c|c|c|c|c|c|}
\hline Kanji & Yomigana & Meaning & F & Rank & $\begin{array}{l}\mathrm{N} \text { of } \\
\mathrm{LP}\end{array}$ & $\begin{array}{l}\text { Rank in LP } \\
\text { use }\end{array}$ & $\begin{array}{l}\mathrm{N} \text { of LP } \\
\text { categories }\end{array}$ \\
\hline 分 & Wa & Understand & 1,569 & 1 & 7 & 26 & 1 \\
\hline 行 & I & Go & 985 & 2 & 14 & 10 & 1 \\
\hline 後 & A to & After & 927 & 3 & 18 & 14 & 1 \\
\hline 君 & Ku n & Mr. & 777 & 4 & 2 & 52 & 1 \\
\hline 様 & Sa ma & Sir & 570 & 5 & 0 & 137 & 0 \\
\hline 皆 & Mi na & Everyone & 559 & 6 & 2 & 52 & 1 \\
\hline 私 & Wa ta shi & I & 546 & 7 & 0 & 137 & 0 \\
\hline 何 & $\mathrm{Nan}$ & How many & 536 & 8 & 4 & 37 & 1 \\
\hline 過 & $\mathrm{Su}$ & Over & 438 & 9 & 0 & 137 & 0 \\
\hline 頑張 & Gan ba & Cheer & 432 & 10 & 20 & 13 & 2 \\
\hline 凄 & Su go & Great & 414 & 11 & 48 & 5 & 3 \\
\hline 今 & I ma & Now & 366 & 12 & 13 & 19 & 1 \\
\hline 本当 & Ho $\mathrm{n}$ to $\mathrm{u}$ & Really & 325 & 13 & 320 & 1 & 3 \\
\hline 着 & Tsu & Arrive & 314 & 14 & 0 & 137 & 0 \\
\hline 来 & $\mathrm{Ku}$ & Come & 287 & 15 & 0 & 137 & 0 \\
\hline 言 & I & Say & 282 & 16 & 150 & 3 & 2 \\
\hline 出 & De & Out & 276 & 17 & 0 & 137 & 0 \\
\hline 俺 & O re & I & 235 & 19 & 12 & 20 & 1 \\
\hline 欲 & Ho & Want & 229 & 20 & 0 & 137 & 0 \\
\hline 所 & To ko ro & Place & 219 & 21 & 140 & 4 & 1 \\
\hline 色々 & I ro i ro & Various & 214 & 22 & 5 & 33 & 2 \\
\hline 了解 & Ryo u ka i & OK & 211 & 23 & 182 & 2 & 5 \\
\hline 見 & $\mathrm{Mi}$ & Watch & 209 & 24 & 0 & 137 & 0 \\
\hline 取 & To & Take & 182 & 25 & 0 & 137 & 0 \\
\hline 何 & Na ni & What & 180 & 26 & 11 & 21 & 3 \\
\hline 来 & $\mathrm{Ki}$ & Come & 168 & 27 & 0 & 137 & 0 \\
\hline 可愛 & Ka wa i & Cute & 156 & 28 & 33 & 7 & 4 \\
\hline 空 & A & Empty & 148 & 29 & 0 & 137 & 0 \\
\hline 婆 & $\mathrm{Ba} \mathrm{a}$ & Grandma & 139 & 30 & 21 & 12 & 2 \\
\hline 来 & $\mathrm{Ku}$ & Come & 137 & 31 & 0 & 137 & 0 \\
\hline 方 & Ho u & To & 136 & 32 & 22 & 11 & 4 \\
\hline
\end{tabular}

Abbreviations. F: Frequency, N: Number, LP: Language plays

Note: ' 0 ' in $\mathrm{N}$ of LP refers to the cases where no LP was applied but simply the standard orthography in hiragana was used. 
Table 12. (Contineud)

\begin{tabular}{|c|c|c|c|c|c|c|c|}
\hline Kanji & Yomigana & Meaning & $n$ & Rank & $\begin{array}{l}\mathrm{N} \text { of } \\
\mathrm{LP}\end{array}$ & $\begin{array}{l}\text { Rank in LP } \\
\text { use }\end{array}$ & $\begin{array}{l}\mathrm{N} \text { of } \mathrm{LP} \\
\text { categories }\end{array}$ \\
\hline 帰 & $\mathrm{Ka} \mathrm{e}$ & Come back & 127 & 33 & 1 & 65 & 1 \\
\hline 飯 & Ha $n$ & Rice/Meal & 104 & 34 & 0 & 137 & 0 \\
\hline 会 & A & Meet & 95 & 35 & 2 & 52 & 1 \\
\hline 頃 & Go ro & About & 93 & 36 & 0 & 137 & 0 \\
\hline 美味 & $\mathrm{O} \mathrm{i}$ & Delicious & 85 & 37 & 3 & 41 & 1 \\
\hline 待 & $\mathrm{Ma}$ & Wait & 83 & 38 & 0 & 137 & 0 \\
\hline 持 & Mo & Have & 83 & 39 & 0 & 137 & 0 \\
\hline 確 & Ta shi & Sure & 76 & 40 & 1 & 65 & 1 \\
\hline 食 & $\mathrm{Ta}$ & Eat & 70 & 41 & 0 & 137 & 0 \\
\hline 物 & Mo no & Things & 68 & 42 & 14 & 17 & 1 \\
\hline 辺 & A ta & Surroundings & 66 & 43 & 8 & 25 & 3 \\
\hline 早 & На уа & Quick & 66 & 44 & 0 & 137 & 0 \\
\hline 色 & I ro & Colour & 65 & 45 & 2 & 52 & 1 \\
\hline 思 & $\mathrm{O}$ mo & Think & 62 & 46 & 0 & 137 & 0 \\
\hline 聞 & $\mathrm{Ki}$ & Listen & 60 & 46 & 0 & 137 & 0 \\
\hline 遅 & O so & Slow & 59 & 48 & 5 & 33 & 2 \\
\hline 始 & Ha ji & Start & 57 & 49 & 0 & 137 & 0 \\
\hline 変 & $\mathrm{Ka}$ & Change & 56 & 50 & 0 & 137 & 0 \\
\hline 達 & Ta chi & (Plural marker) & 56 & 50 & 0 & 137 & 0 \\
\hline
\end{tabular}

\subsection{Use of Small Moji}

There are 136 examples of small moji use in the Hiragana versions of 44 words which are generally written in Kanji. Table 13 shows the top 10 words which contain small moji as a replacement for large moji. Table 13. Top 10 Hiragana conversions using small moji applications (Abbreviation. LP: Language plays)

\begin{tabular}{|c|c|c|c|c|c|}
\hline Kanji & Patterns & Romaji & Frequency & Proportion in total LP & Total LP \\
\hline 後 & あと & $\underline{A}$ to & 18 & $100.00 \%$ & 18 \\
\hline 行 & $\underline{\omega}$ & $\underline{I}$ & 14 & $58.33 \%$ & 24 \\
\hline 今 & しま & $\underline{I} \mathrm{ma}$ & 13 & $100.00 \%$ & 13 \\
\hline 俺 & 求れ & $\underline{\mathrm{O}} \mathrm{re}$ & 12 & $100.00 \%$ & 12 \\
\hline 婆 & ば西 & $\mathrm{Ba} \underline{\mathrm{a}}$ & 8 & $38.10 \%$ & 21 \\
\hline 分 & わ & $\underline{\mathrm{Wa}}$ & 7 & $100.00 \%$ & 7 \\
\hline 早 & はゃ & Ha ya & 6 & $75.00 \%$ & 8 \\
\hline 方 & ほ之 & Ho $\underline{\mathrm{u}}$ & 5 & $22.73 \%$ & 22 \\
\hline 遅 & 戈そ & $\mathrm{O} \underline{\text { so }}$ & 4 & $80.00 \%$ & 5 \\
\hline 大分 & だいぶ & $\mathrm{Da} \underline{\mathrm{i}} \mathrm{bu}$ & 4 & $100.00 \%$ & 4 \\
\hline
\end{tabular}


For example, 行 is written using a small vowel い instead of い. Fourteen examples of 行 are written this way of the total of 24 patterns of Hiragana usage for 行 found in the collected Keitai-mail data. Therefore, い accounts for $58.33 \%$ of the pattern of LP applications.

Small moji uses are restricted by the syllables used for yomigana. If yomigana contain syllables which usually cannot be written in small moji, this pattern naturally does not occur. This means that if yomigana contain あ, い, う, え,お，つ，や，ゆ，ょ，わ， this pattern is possible. The words shown in Table 6.8 only show a single pattern of small moji use, but one word elsewhere in the corpus, 可愛, exhibits two patterns of small moji use (かわ兄 and かわい).

\subsection{Long Vowel Symbols}

30 words are written in Hiragana with the replacement of some vowels by long vowel symbols in 237 cases, something not normally done in written Japanese. Table 14 illustrates the words with two or more occurrences of this type of LP. Table 14 suggests that j/u/ is the main moji replaced by long vowel symbols.

Table 14. Top 9 Hiragana conversions with replacement of long vowel symbols

\begin{tabular}{|c|c|c|c|c|c|}
\hline Kanji & Patterns & Romaji & Frequency & Proportion in total LP & Total LP \\
\hline 了解 & りょ一かい & Ryo u ka i & 135 & $74.18 \%$ & 182 \\
\hline 超 & $\begin{array}{l}ち ょ \sim \\
ち ょ-\end{array}$ & Cho $\underline{\mathrm{u}}$ & 23 & $92.00 \%$ & 25 \\
\hline 大丈夫 & だいじょーぶ & Da i jo $\underline{u}$ bu & 20 & $51.28 \%$ & 39 \\
\hline 婆 & ばー & $\mathrm{Ba} \underline{\mathrm{a}}$ & 13 & $61.90 \%$ & 21 \\
\hline 姉 & ね- & $\mathrm{Ne} \underline{\mathrm{e}}$ & 10 & $90.91 \%$ & 11 \\
\hline 兄 & に一 & $\mathrm{Ni} \underline{\mathrm{i}}$ & 6 & $100.00 \%$ & 6 \\
\hline 即効 & そっこ一 & So kko $\underline{\mathrm{u}}$ & 6 & $100.00 \%$ & 6 \\
\hline 普通 & 3.つ一 & $\mathrm{Hu}$ tsu $\underline{\mathrm{u}}$ & 3 & $100.00 \%$ & 3 \\
\hline 適当 & てきと〜 & Te ki to $\underline{\mathrm{u}}$ & 2 & $50.00 \%$ & 2 \\
\hline
\end{tabular}

Note. Rank 10 and upwards have only one pattern and are therefore omitted from the table.

Abbreviation. LP: Language plays

\subsection{Use of Syllables other than Orthography}

337 examples which contain Hiragana conversion with syllable replacement were found for 37 words. Table 15 shows the top 10 most frequent words using this form of LP.

This pattern, in theory, has unlimited application. For example, 頑張 has three types of application patterns: が んぱ is a replacement of the dakuon (syllable with “"’) with handakuon (syllables with “o'); がむば makes a replacement within the word itself, $ん$ to む; かんば involves replacement of the first syllable, instead of the second syllable like the other two. However, this replacement seems basically to be a phonological contraction, and not too far outside the general rules of Japanese language.

\subsection{Omission of Elements}

There are 490 examples omitting an element in yomigana writing, and this category accounts for the largest numbers of LP. However, only 12 words exhibit this pattern, indicating that this pattern can include certain LP application patterns which frequently occur in this particular category.

Table 16 shows the full set of words which exhibit this LP pattern. 本当 and 所 account for a large proportion $(89 \%)$. These two are ranked in the top 2 places in terms of the number of LP applications in a word. Other than these two, the numbers are small. In this case too, j/u/ is replaced in many words, and in addition to long vowel symbol use, j/u/ can be easily changed or omitted in this type of communication. 
Table 15. Top 10 Hiragana conversions including replacement of syllable

\begin{tabular}{|c|c|c|c|c|c|}
\hline Kanji & Pattern & Romaji & $\mathrm{F}$ & Proportion in total LP & Total LP \\
\hline 言 & $\Phi(い)$ & $\underline{\mathrm{Yu}}$ (i) & 149 & $99.33 \%$ & 150 \\
\hline 暖 & あ己(た)た & $\mathrm{A} \underline{\operatorname{xtus}}^{3}$ (ta) ta & 32 & $100.00 \%$ & 32 \\
\hline 凄 & すげ(ご) & Su ge (go) & 24 & $50.00 \%$ & 48 \\
\hline 頑張 & $\begin{array}{l}\text { がんぱ(ば) } \\
\text { がむ(ん)ば } \\
\text { か(が)んば }\end{array}$ & $\begin{array}{l}\text { Ga n pa (ba) } \\
\text { Ga } \underline{\mathrm{mu}}(\mathrm{n}) \mathrm{ba} \\
\underline{\mathrm{Ka}}(\mathrm{Ga}) \mathrm{n} \mathrm{ba}\end{array}$ & 19 & $95.00 \%$ & 20 \\
\hline 方 & ほ㧈(う) & Ho $\underline{x o}(\mathrm{u})$ & 14 & $63.64 \%$ & 22 \\
\hline 物 & 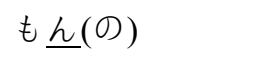 & Mo $\underline{\mathrm{n}}(\mathrm{no})$ & 14 & $100.00 \%$ & 14 \\
\hline 了解 & 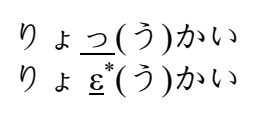 & $\begin{array}{l}\text { Ryo xtsu (u) ka i } \\
\text { Ryo } \underline{(u) ~ k a ~ i ~}\end{array}$ & 11 & $6.04 \%$ & 182 \\
\hline 悪 & $\begin{array}{l}\text { わ(る) } \\
\text { や(わ)る }\end{array}$ & $\begin{array}{l}\text { Wa } \underline{\text { ri }(r u)} \\
\underline{\text { Ya }} \text { (Wa) ru }\end{array}$ & 10 & $90.91 \%$ & 11 \\
\hline 結構 & けっこ抢(う) & Ke kko o $(\mathrm{u})$ & 6 & $66.67 \%$ & 9 \\
\hline 可愛 & $\begin{array}{l}\text { かわえ(い) } \\
\text { かわゆ(い) }\end{array}$ & $\begin{array}{l}\text { Ka wa e (i) } \\
\text { Ka way } \underline{u} \text { (i) }\end{array}$ & 6 & $18.18 \%$ & 33 \\
\hline 下 & く占(だ) & $\mathrm{Ku} \underline{\mathrm{ra}}(\mathrm{da})$ & 6 & $85.71 \%$ & 7 \\
\hline 疲 & $\underline{\hbar}(\supset)$ か & 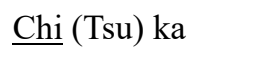 & 6 & $85.71 \%$ & 7 \\
\hline
\end{tabular}

Note. The underlining shows the replacement and the syllable in parenthesis following is the orthography.

Abbreviations. F: Frequency, LP: Language plays

${ }^{*} \varepsilon$ indicates the use of emoticons

\subsection{Additions in conversion}

109 examples for 40 words are categorised in this group. Table 17 shows the top 10 words in which extra syllables/symbols not normally occurring in standard written Japanese were added in Hiragana conversion. The table shows several patterns of addition: extra long vowel symbols (なこに), extra 'つ’(すつご), extra ‘ん’ (な んに), extra small vowel following on from the preceding syllable (なあに), and other patterns (りょうのかい). Ultimately, anything can be added to form this pattern; however, added components should not have the ability to change the meaning of the original word, and basically only a small number of extra words are added in the process of conversion to Hiragana.

Table 16. Hiragana conversion with omissions

\begin{tabular}{llllll}
\hline Kanji & Pattern & Romaji & F & Proportion in total LP & $\begin{array}{l}\text { Total } \\
\text { LP }\end{array}$ \\
\hline 本当 & ほんと(う) & Ho n to (u) & 297 & $92.81 \%$ & 320 \\
所 & とこ(ろ) & To ko (ro) & 140 & $100.00 \%$ & 140 \\
嫌 & $($ (や & (I) ya & 15 & $93.75 \%$ & 16 \\
了 & りょ(う) & Ryo (u) & 10 & $66.67 \%$ & 15 \\
大丈夫 & だいじょ(う)ぶ & Da i jo (u) bu & 8 & $20.51 \%$ & 39 \\
了解 & クょ(う)かい & Ryo (u) ka i & 6 & $3.30 \%$ & 182 \\
\hline
\end{tabular}




\begin{tabular}{llllll}
\hline 先生 & せんせ $($ ( $)$ & Se n se (i) & 6 & $100.00 \%$ & 6 \\
方 & ほう) & Ho (u) & 2 & $9.09 \%$ & 22 \\
一応 & いちお(う) & I chi o (u) & 2 & $14.29 \%$ & 14 \\
中 & ちゅ(う) & Chu (u) & 1 & $50.00 \%$ & 2 \\
勉強 & べんき & Be n kyo (u) & 1 & $100.00 \%$ & 1 \\
放 & ほう) & Ho (u) & 1 & $100.00 \%$ & 1 \\
\hline
\end{tabular}

Note. The moji in parentheses indicate the moji omitted. Abbreviations. F: Frequency, LP: Language plays

\subsection{Capitalisation}

In a few cases, several Hiragana are written in big moji instead of small moji. Table 18 shows four words which exhibit this pattern. Only four small Hiragana $\supset, や ゆ, ょ$ are used in normal Japanese orthography and therefore this category too only appears infrequently compared to other patterns.

Table 17. Top 10 words of Hiragana conversion with additional parts

\begin{tabular}{|c|c|c|c|c|c|}
\hline Kanji & Pattern & Romaji & $\mathrm{F}$ & Proportion in total LP & Total LP \\
\hline 凄 & $\begin{array}{l}\text { すっご } \\
\text { すっつご } \\
\text { すんご }\end{array}$ & $\begin{array}{l}\text { Su xtsu go } \\
\mathrm{Su} \underline{\mathrm{xtsu}} \underline{\mathrm{xtsu}} \text { go } \\
\mathrm{Su} \underline{\mathrm{n}} \mathrm{go}\end{array}$ & 21 & $43.75 \%$ & 48 \\
\hline 了解 & 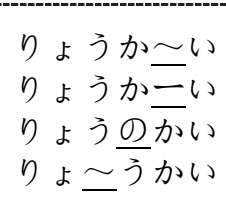 & $\begin{array}{l}\text { Ryo u ka } \simeq \mathrm{i} \\
\text { Ryo u ka }=\mathrm{i} \\
\text { Ryo u no ka i } \\
\text { Ryo } \simeq \text { u ka i }\end{array}$ & 16 & $8.79 \%$ & 182 \\
\hline 何 & 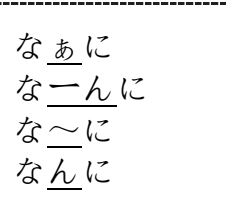 & $\begin{array}{l}\mathrm{Na} \times \mathrm{xi} \\
\mathrm{Na}=\underline{\mathrm{n}} \mathrm{ni} \\
\mathrm{Na} \simeq \mathrm{ni} \\
\mathrm{Na} \underline{\mathrm{n}} \mathrm{ni}\end{array}$ & 7 & $63.64 \%$ & 11 \\
\hline 大 & だ二い & $\mathrm{Da}=\mathrm{i}$ & 7 & $100.00 \%$ & 7 \\
\hline 全然 & 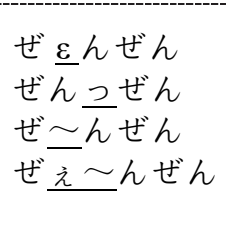 & $\begin{array}{l}\text { ZeEn ze } \mathrm{n} \\
\mathrm{Ze} \mathrm{n} \underline{\mathrm{xtsu}} \text { ze } \mathrm{n} \\
\mathrm{Ze} \simeq \mathrm{n} \text { ze } \mathrm{n} \\
\mathrm{Ze} \underline{\mathrm{xe}} \simeq \mathrm{n} \text { ze } \mathrm{n}\end{array}$ & 6 & $100.00 \%$ & 6 \\
\hline 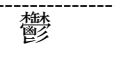 & j2 & U xtsu tsu & 5 & $100.00 \%$ & 5 \\
\hline 何 & $\begin{array}{l}\text { な二h } \\
\text { なこh }\end{array}$ & $\begin{array}{l}\mathrm{Na}=\mathrm{n} \\
\mathrm{Na} \simeq \mathrm{n}\end{array}$ & 4 & $100.00 \%$ & 4 \\
\hline 熱 & あっつ & A xtsu tsu & 4 & $100.00 \%$ & 4 \\
\hline 素晴 & $\begin{array}{l}\text { すっば } \\
\text { す允ば }\end{array}$ & $\begin{array}{l}\text { Su xtus ba } \\
\text { Su n ba }\end{array}$ & 3 & $100.00 \%$ & 3 \\
\hline 絶対 & $\begin{array}{l}\text { ぜ烏 } \\
\text { ぜっつたい } \\
\text { ぜこったい }\end{array}$ & $\begin{array}{l}\mathrm{Ze} \equiv \text { ttai } \\
\mathrm{Ze} \underline{\text { xtus }} \text { tai } \\
\mathrm{Ze} \simeq \text { ttai }\end{array}$ & 3 & $100.00 \%$ & 3 \\
\hline
\end{tabular}

Abbreviations. F: Frequency, LP: Language plays 
Table 18. Words involving Hiragana conversion with capitalisation

\begin{tabular}{|c|c|c|c|c|c|}
\hline Kanji & Pattern & Romaji & $n$ & Proportion in total LP & Total LP \\
\hline 誕生日 & たんじょうび & Ta n ji yo u bi & 2 & $66.67 \%$ & 3 \\
\hline 勝手 & かつて & Ka tsu te & 1 & $25.00 \%$ & 4 \\
\hline 執念 & しゅうねん & Shi yu u ne n & 1 & $100.00 \%$ & 1 \\
\hline 盤石 & ばんじやく & Ba n ji ya ku & 1 & $100.00 \%$ & 1 \\
\hline
\end{tabular}

99 examples for 17 words apply two or more patterns of LP. Several such combination patterns are shown in the collected Keitai-mail data:

- Long vowel symbol use and additional parts: りょ二か二いたりょうかい

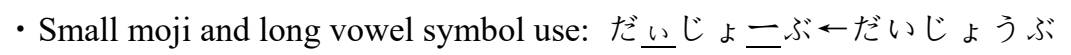

- Capitalisation and omission: りょかいたりょうかい

In addition, a few examples reverse the sequence of yomigana syllables, such as $し \sim \bigotimes$, which is a Hiragana conversion of 飯, read $め L / m e$ shi/: the syllables $め$ and $L$ are reversed (and a long vowel symbol is added in the middle). Table 19 illustrates all cases found in the data. In theory, a vast number of patterns is possible if users apply many LP all at once, but the data corpus does not include any such extreme cases: basically, the application of LP is limited.

Table 19. Hiragana conversion with combinations of language plays

\begin{tabular}{|c|c|c|c|c|c|}
\hline Kanji & Pattern & Orthography & $F$ & Proportion in total LP & Total LP \\
\hline 可愛 & 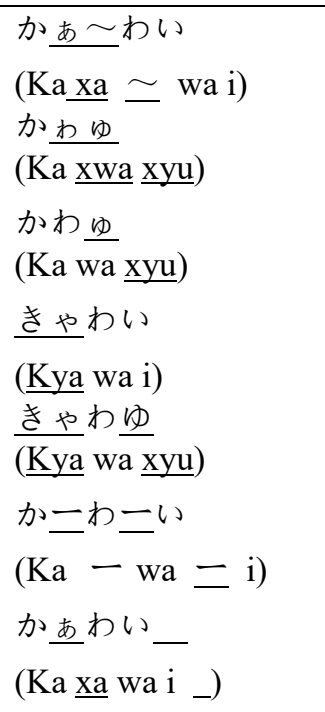 & $\begin{array}{l}\text { かわい } \\
\text { (Ka wa i) }\end{array}$ & 23 & $69.70 \%$ & 33 \\
\hline 本当 & 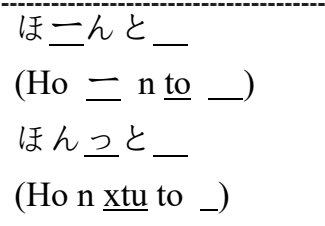 & $\begin{array}{l}\text { ほんとう } \\
\text { (Ho n to u) }\end{array}$ & 21 & $6.56 \%$ & 320 \\
\hline 大丈夫 & $\begin{array}{l}\text { だらじょ二ぶ } \\
\text { (Daxi jo 二 bu) } \\
\text { だいじょ_ぶ二 } \\
\text { (Da i jo - bu 二) } \\
\text { だいぢょ二ぶ } \\
\text { (Da xi di xyo 二 bu) }\end{array}$ & $\begin{array}{l}\text { だいじょうぶ } \\
\text { (Da i jo u bu) }\end{array}$ & 9 & $23.08 \%$ & 39 \\
\hline
\end{tabular}


Table 19. (Continued)

\begin{tabular}{|c|c|c|c|c|c|}
\hline Kanji & Pattern & Orthography & $\mathrm{F}$ & Proportion in total LP & Total LP \\
\hline 了解 & 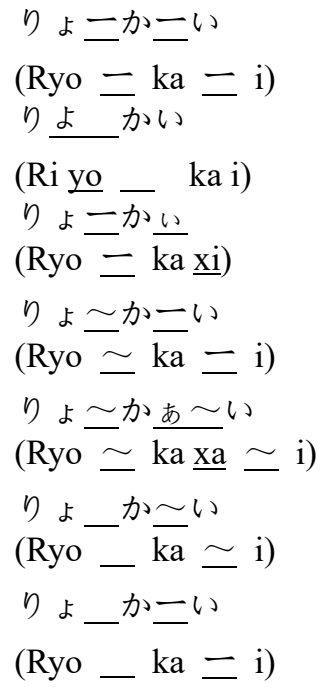 & $\begin{array}{l}\text { クょうかい } \\
\text { (Ryo u ka i) }\end{array}$ & 14 & $7.69 \%$ & 182 \\
\hline 凄 & $\begin{array}{l}\text { すっげ } \\
(\text { Su xtu ge })\end{array}$ & $\begin{array}{l}\text { すご } \\
(\mathrm{Su} \text { go })\end{array}$ & 3 & $6.25 \%$ & 48 \\
\hline 一応 & 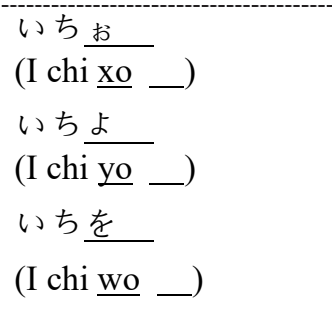 & $\begin{array}{l}\text { いちおう } \\
\text { (I chi o u) }\end{array}$ & 8 & $57.14 \%$ & 14 \\
\hline 何 & 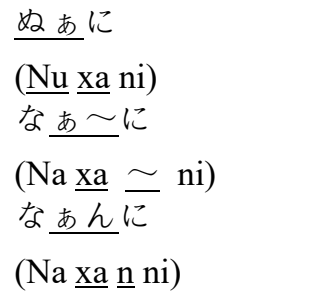 & $\begin{array}{l}\text { なに } \\
\text { (Na ni) }\end{array}$ & 3 & $27.27 \%$ & 11 \\
\hline 飯 & 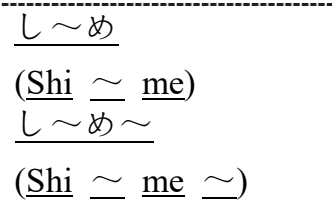 & $\begin{array}{l}\text { め } \\
\text { (Me shi) }\end{array}$ & 3 & $100.00 \%$ & 3 \\
\hline 超 & $\begin{array}{l}5 ょ=- \\
(\text { Cho 二- }) \\
\text { ょ二-二 } \\
(\text { Cho 二-二 })\end{array}$ & $\begin{array}{l}\text { ちょう } \\
\text { (Chou) }\end{array}$ & 2 & $8.00 \%$ & 25 \\
\hline 了 & 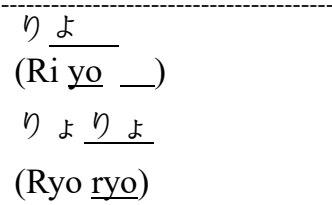 & $\begin{array}{l}\text { りょう } \\
\text { (Ryo u) }\end{array}$ & 2 & $13.33 \%$ & 15 \\
\hline
\end{tabular}


Table 19. (Continued)

\begin{tabular}{|c|c|c|c|c|c|}
\hline Kanji & Pattern & Orthography & $\mathrm{F}$ & Proportion in total LP & Total LP \\
\hline 結構 & $\begin{array}{l}\text { けっこ㧈 } \\
(\text { Ke xtu ko xo })\end{array}$ & $\begin{array}{l}\text { けっこj } \\
(\text { Ke xtu ko u) }\end{array}$ & 2 & $22.22 \%$ & 9 \\
\hline 色々 & $\begin{array}{l}\frac{\omega}{3} \underline{2} \\
\text { (xi ro } \underline{2})\end{array}$ & $\begin{array}{l}\text { いろいろ } \\
\text { (I ro i ro) }\end{array}$ & 2 & $40.00 \%$ & 5 \\
\hline 暇 & $\begin{array}{l}\left.\frac{ま \sim \mho}{(\mathrm{Ma} \sim} \underline{\mathrm{hi}}\right) \\
\text { ま一 } \\
(\underline{\mathrm{Ma}}=\underline{\mathrm{hi}})\end{array}$ & $\begin{array}{l}\text { ひま } \\
\text { (Hi ma) }\end{array}$ & 2 & $100.00 \%$ & 2 \\
\hline 頑張 & $\begin{array}{l}\text { ぎゃんば } \\
\text { ( } \underline{\text { Gya }} \text { n ba) }\end{array}$ & 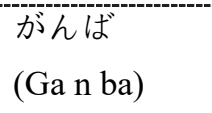 & 1 & $5.00 \%$ & 20 \\
\hline 用 & $\begin{array}{l}\text { よ求 } \\
\text { (Yo } \underline{x o})\end{array}$ & $\begin{array}{l}\text { よう } \\
(\mathrm{Yo} \mathrm{u})\end{array}$ & 1 & $100.00 \%$ & 1 \\
\hline 騒 & $\begin{array}{l}\text { さがわ } \\
\text { (Sa ga wa) }\end{array}$ & $\begin{array}{l}\text { さわが } \\
\text { (Sa wa ga) }\end{array}$ & 1 & $100.00 \%$ & 1 \\
\hline
\end{tabular}

\subsection{Variety of LP Application}

There are six basic LP patterns and many patterns of combination. The actual data suggest that each Kanji is converted to Hiragana using one main pattern of LP. Table 20 shows the average proportion of use for each LP. This suggests that for each Kanji only one type of LP tends to be applied, which is why the average proportions are relatively high. For example, Table 21 shows the case of 了解. Here, the conversion exhibits four different LP and combinations of LP, and almost $75 \%$ (3/4) of the patterns involve long vowel symbol use. As this example shows, for each Kanji there is a preferred application of LP when converting to Hiragana.

Table 20. The average proportion of occurrence of each language play for the top 10 words

\begin{tabular}{|c|c|c|c|c|c|c|}
\hline Small moji & $\begin{array}{l}\text { Long } \\
\text { symbol }\end{array}$ & vowel & Replacement & Omission & Addition & Capitalisation \\
\hline $77.42 \%$ & $80.03 \%$ & & $71.77 \%$ & $62.54 \%$ & $81.62 \%$ & $72.92 \%$ \\
\hline
\end{tabular}

Table 21. The proportion of language play patterns applied to 了解

\begin{tabular}{lllll}
\hline Long vowel symbol & Replacement & Omission & Addition & Combination \\
\hline $74.18 \%$ & $6.04 \%$ & $3.30 \%$ & $8.79 \%$ & $7.69 \%$ \\
\hline
\end{tabular}

\subsection{Kanji replaced by Katakana}

In some cases, Kanji which are replaced by Katakana are found in the corpus, and this section discusses this phenomenon in sequence with the previous section. In total, 949 words involving 133 Kanji were converted to Katakana. When compared with Hiragana conversions of Kanji (17,801 words, 749 Kanji), Katakana conversions are much less frequent (5.3\%). In terms of the number of how many Kanji are converted, the proportion is smaller than the number of occurrences: the proportion between the number of Kanji converted to Hiragana and those converted to Katakana is approximately 18\% (133/749), so that cases where Kanji are converted into Katakana only are quite rare.

Table 22 shows Katakana replacements for Kanji. The first illustrates the top 20 Kanji replaced by Katakana; it includes the original Kanji, its yomigana reading, and replacement patterns found in the corpus based on the application of LP as discussed in the section on Hiragana conversions. The second introduces some other Kanji which are not shown in Table 6.17 where two or more LP patterns have been applied in the conversion. 
Table 22. Top 20 Kanji replaced by Katakana

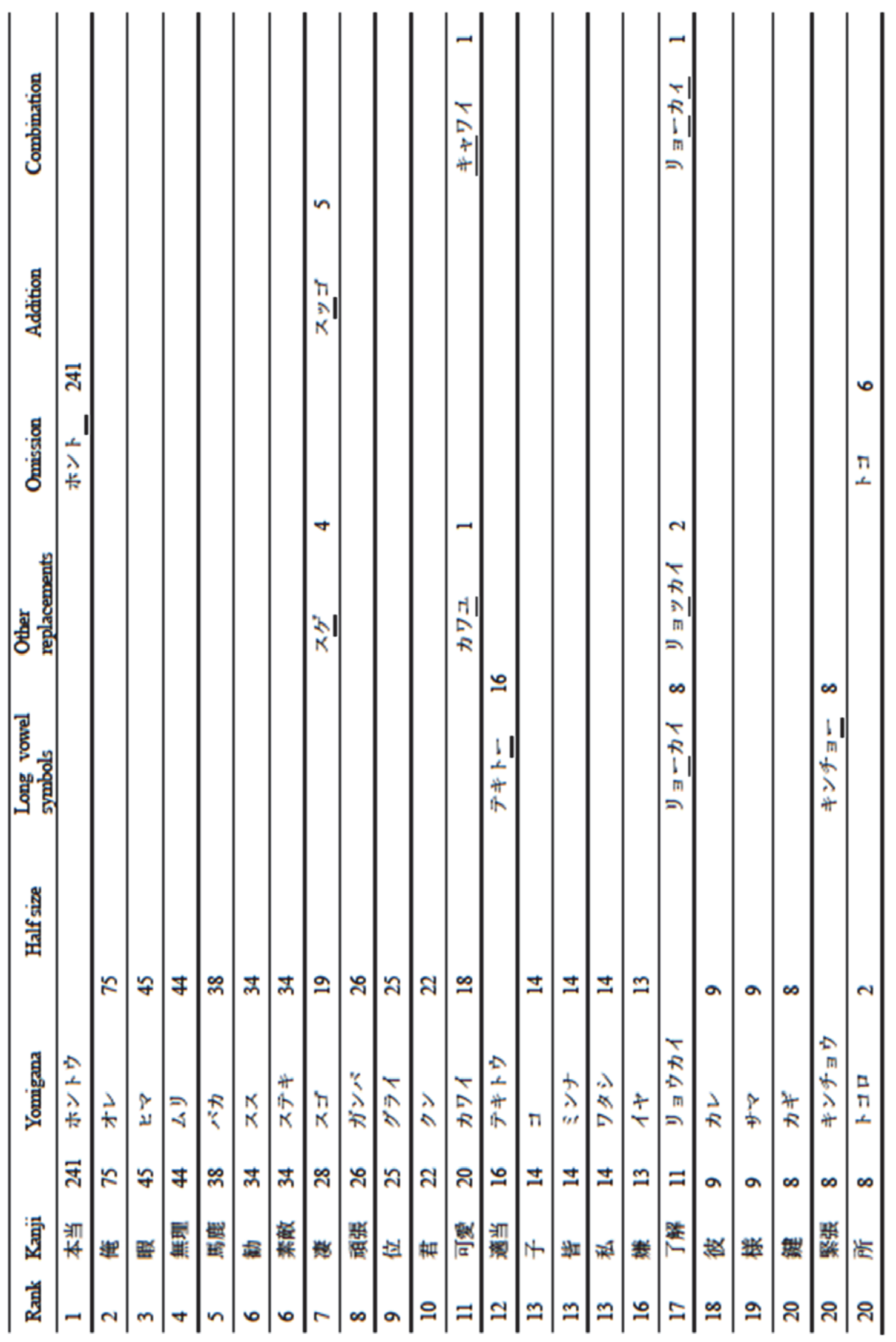


A striking feature of this table is the 241 occurrences of 本当 /ho $n$ to $\mathrm{u} /$, which ranked in the first place. Instead of the usual yomigana ホントウ, a shortened version，ホント, appears 241 times, which means that in $100 \%$ of 本当 conversions to Katakana, reduction LP has been applied. Reducing the yomigana $/ \mathrm{u} /$ is also seen in Hiragana conversion (omitting j, 297 in 325 replacements), and this is a strong tendency related to the word 本 当.

Other than this pattern, the LP applications are quite limited. Only 92 other LP patterns are found for 24 Kanji (therefore, only 25 of the 133 Kanji apply LP in Katakana conversions). Glancing at the proportion of LP use in Katakana conversion, we find approximately 35\% (333 in 949) of conversions which utilise some kind of LP. However, the ホント pattern accounts for 72\% (241/333) of replacement with LP and the proportion of application of LP to other Kanji is less than $13 \%$ (i.e., 92/708), just slightly higher than the proportion for Kanji-Hiragana conversion (where it accounted for less than 8\%). Therefore, as with Hiragana, LP do not stimulate a preference for replacing Kanji with Katakana.

One particular LP aspect found only in Kanji-Katakana conversion is the addition of a dot ('• ') between yomigana symbols: ヒ・ミ・ツ/hi mi tsu/ and シ・ゴ・ト/shi go to/. The use of extra dots gives a different rhythm to the word, but there are only two cases where this pattern is used.

To consider the conversions from a technical perspective, Katakana conversion requires extra effort. The Keitai input system first displays Hiragana and then converts it to Kanji or Katakana. Current Japanese mobile phones come with an installed conversion prediction system which enables efficient input of Kanji based on information from the dictionary as to how each combination of Hiragana will be converted, as well as on the history of how users have converted it before. However, Katakana conversion is not well catered for in the dictionary in terms of the prediction system. This means that users need to fully input words to convert Katakana, or they need to change the input mode to a 'Katakana input' mode. Therefore, Katakana conversion itself is demanding for the user and will be chosen only when a particular intention is involved.

\section{Discussion}

The result shows that overall pictures of components used in Keitai-mail has an affinity of previous studies. Regarding the functions of Emoji used as replacements, some incorporate a 'body-language' aspect (e.g., Arabic numerals which can be expressed by fingers in face-to-face communication), and others have 'phonological features' (e.g., Emoji seeming like long vowel symbols). As Kimura (2002) suggests, Emoji are recognised mainly as pictures and not as alternatives for words written in script, and this corresponds with these styles. At the same time, however, currently it seems people now use Emoji more actively than in the past as a replacement for words, as shown above. This may be explained by 1) technical growth of extension of Emoji installed in each Keitai, or 2) increasing experiences of Keitai-mail practices which allow people to use and interpret a wider range of Emoji more accurately than in the past.

One great factor to the use of non standard is attributed Conversion and technical demands. The 'extra demand' factor which limits Katakana conversion seems to hold true for Kanji-based conversion as a whole. Table 23 summarises how many Kanji-Hiragana/Katakana conversions appeared in the data corpus. Although LP application in Kanji-Hiragana/Katakana conversions is restricted by yomigana as discussed in the Kanji-Hiragana conversion section, and misinterpretation of the original meaning as a result of LP is avoided, the table shows that compared to Hiragana in yomigana conversion the number of conversions by other methods appears quite small, and the large differences here indicate the influence of the technology, in addition to the Hiragana-Katakana differences discussed in the previous section.

Table 23 also shows the tendency of input demand influences. Even though the use of LP is an intentional act which adds extra information, participants also choose a not-too-complicated technique to achieve it. Of the six LP patterns, omission is the most frequent. Since omission can decrease the effort involved in input, users tend to favour this as long as the words with omissions still make sense (e.g., 本当 /hon to u/ vs /hon to/; 所/to ko ro/ vs /to ko/), and this pattern is sometimes preferred to giving the full yomigana orthography.

Moreover, of the three replacement techniques of half-size symbols, long vowel symbols, and replacements with other symbols, small-moji replacement is applied least. This can be attributed also to the input specification that even though these replacement patterns do not change the total number of symbols in a word (i.e., it has the same number of symbols as in the normal yomigana version), replacement with half-size symbols requires the use of irregular half size-symbols, particularly half-size vowels, which are rarely used in writing Japanese words. This increases the number of key strokes involved in producing them and may not be so popular when applied to inputting Kanji where the prediction conversion system can ease the burden: basically, users can obtain the intended Kanji through minimum Hiragana input. 
Table 23. The number of Hiragana/Katakana conversions from Kanji

\begin{tabular}{lll}
\hline Pattern & Hiragana & Katakana \\
\hline Just as yomigana & 16,388 & 616 \\
Replacement with half-size symbols & 136 & 2 \\
Long vowel symbols & 237 & 59 \\
Other replacement & 337 & 11 \\
Omission of components & 490 & 248 \\
Additional components & 109 & 8 \\
Use of full-size symbols & 6 & 0 \\
Combination/other patterns & 98 & 5 \\
\hline Total & 17,801 & 949 \\
\hline
\end{tabular}

The difference between replacements with half-size symbols and with other symbols is that the latter entails unintentional factors, such as mistyping or pronunciation of dialect and contraction. For example, 言 /i/ is more often pronounced as /yu/ in the western part of Japan, or 暖 /a ta ta/ is frequently pronounced as /atta/ (e.g., あ つたかい /a tta kai/) in natural Japanese. To distinguish whether something has been mistyped or not is not easy

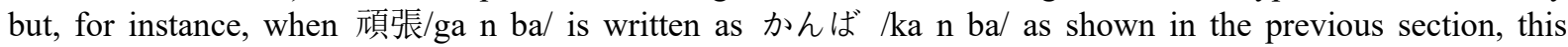
seems to be a simple case of mistaken input since かんば is not generally seen. Therefore, the relatively high frequency of this pattern does not run counter to the tendency of users to avoid too many input demands.

The increase in key strokes required for applications of additional moji uses and combination patterns may limit the use of these techniques to less than the LP applications shown earlier because these patterns increase the number of key strokes compared with the key stroke input for yomigana.

\section{Conclusion}

This study analyzed languages uses in Japanese Keitai including non-standard uses of language, and show that Keitai-mail is short: the average length is 40 letters. The average number of genres contained in each mail is 2.4. The data show that Keitai-mail is longer texts than the very truncated messages which occur in the totally seamless text communication of Internet chat.

Most of Keitai-mail are of course are within the standard rules of Japanese language, but the five types of scripts and picture based symbols are uniquely used beyond the rule. For example, Emoji play an important role in providing extra-textual meaning which increases effectiveness of communication and mutual intelligibility.

In addition, conversions from Kanji involve many factors: the frequency of the words themselves, yomigana and the restrictions it places on LP applications, relationship between the original words and their LP-applied patterns, naturalness as Japanese language itself, and technical reasons, but the result seems to be influenced most by word frequency itself and by specification matters which unconsciously limit the users' creativity.

LP are applied in a limited manner with a certain level of systematicity in order not to interfere with communication with interlocutors. In other words, people create Keitai-mail in such a way as not to violate the interlocutor's expectation of messages (which should follow the rule of adjacency pairs) in order to maintain mutual intelligibility.

The highlighted contribution of this study is its holistic re-examination, through investigation of an extremely large Keitai-mail data corpus, of phenomena which have been separately reported in smaller studies over the last two decades. As Crystal (2008) notes, obtaining raw data is always a challenging task for researchers, particularly the data of text-based message exchanges which include a great deal of personal information. From one perspective, this limitation can stimulate researchers to devise methodologies; effective proposed methods to overcome limitations enable them to develop innovative means of gaining meaningful results from the available sources. Despite the difficulty of data collection, thanks to all participants, this study was able to analyze the nature of Keitai-mail using a great number of raw data sets, and the results and discussions in this study both give critical evidence to support phenomena previously found in smaller studies and also offer further insights 
into Keitai-mail practice in a more systematic manner. Also, this study indicates the effectiveness of alternative methodologies devised in previous studies by comparing how their results correspond with the result obtained from its raw data.

\section{Acknowledgments}

This paper is based on my Ph.D. dissertation, and I would like to show my appreciation to Emeritus Professor Nanette Gottlieb Dr. Yuriko Nagata and Dr. Michael Harrington. In addition, I would like to extend my thanks to Emeritus Professor Nanette Gottlieb, the University of Queensland, for proofreading this work. Moreover, this research project was supported by several scholarships and a research grant: The University of Queensland, the Faculty of Arts International Scholarship. Nanette Gottlieb's Australian Professorial Fellowship, funded by the Australian Research Council. Tokyo Foundation.

\section{References}

Azuma. J, \& Ebner, M. (2008). A Stylistic Analysis of Graphic Emoticons: Can they be Candidates for a Universal Visual Language of the Future? Proceedings of World Conference on Educational Media, Hypermedia and Telecommunications (ED-Media), 972-977.

Crystal, D. (2008). Txtng: The Gr8 Db8. Oxford: Oxford University Press.

Hård af Segerstad, Y. (2005). Language in SMS - A socio-linguistic view. In R. Harper, L. Palen \& A. Taylor (Eds.), The inside text: Social, cultural and design perspectives on SMS (pp. 33-51). Dordrecht: Springer.

Hayashi, R. (2007). Industrial design changes and social trends in view of mobile phone history. Sharp Technical Journal, 95, 24-28.

Horasawa, S. (2005). Overlapping communication space among young people: Face-to-face communication and e-mail communication by portable phones. Bulletin of the Faculty of Regional Studies, Gifu University, 17, $1-20$.

Ito, M. (2005). Introduction: Personal, Portable, Pedestrian. In M. Ito, D. Okabe \& M. Matsuda (Eds.), Personal, Portable, Pedestrian: Mobile phones in Japanese life (pp. 1-16). Cambridge: The MIT Press.

Ito, M., \& Okabe, D. (2005). Technosocial situations: Emergent structuring of mobile E-mail use. In M. Ito, D. Okabe \& M. Matsuda (Eds.), Personal, Portable, Pedestrian: Mobile phones in Japanese life (pp. 257-273). Cambridge: The MIT Press.

Jungle. Inc. (2009) Keitai-master MX ver4.5 [Computer software].

Kato, S., Kato, Y., Kobayashi, M., \& Yanagisawa, M. (2007). Analysis of the kinds of emotions interpreted from the emoticons used in e-mail. Kyōiku Jōhō Kenkyū, 22(4), 31-39.

Kawakami, M. (2008). A database of 31 Japanese emoticons with their emotions and emphases. The Human Science Research Bulletin of Osaka Shoin Women's University, 7, 67-82.

Kimura, M. (2002). 媒体に依存する表現-携帯メールの場合 [Expressions which depend on the medium: The case of mobile phone e-mail]. Reports of the Osaka Shoin Women's University Japanese Language Research Center, 10, 35-48.

Miyake, K. (2004). 「規範からの逸脱」志向の系譜一携帯メールの表記をめぐって [Beyond the standard use of language:About the language of mobile phone e-mail]. Bungaku Ronsō, 78, 1-15.

Miyake, K. (2007). How young Japanese express their emotions visually in mobile phone messages: A sociolinguistic analysis. Japanese Studies, 27(1), 53-72. Doi https://doi.org/10.1080/ 10371390701268646

Mizuta, N., Doi, Y., \& Yamamoto, K. (2004). An error analysis of polite expressions used by Japanese learners in text messages on the cell phone email system. The Bulletin of Kurashiki University of Science and the Arts, 9, 237-247.

Nishimura, Y. (2003). Linguistic innovations and interactional features of casual online communication in Japanese. Journal of Computer-Mediated Communication, 9(1). Doi: https://doi.org/10.1111/ j.1083-6101.2003.tb00356.x

Ono, S., \& Tokuda, K. (2005). 高校生・大学生・主婦における携帯メールの顔文字使用の実態と意識 [The consciousness and reality of emoticon use in mobile e-mail among high school students, university students and housewives]. The Science of Reading, 49(1), 22-32.

Sakai, N. (2013).The role of sentence closing as an emotional marker: a case of Japanese mobile phone e-mail. Discourse, Context and Media, 2(3), 149-155. https://doi.org/10.1016/j.dcm.2013.07.001 
Sasahara, H. (2002). Characteristics of and the influence of orthography on cell-phone e-mail. The Japanese Journal of Language in Society, 5(1), 105-116. Doi https://doi.org/10.19024/jajls.5.1_105

Sasaki, N., \& Ishikawa, K. (2006). Comparative study of the sentence of students' reports produced between PC-mail and mobile phone-mail. Bulletin of Kyoto University of Education, 109, 99-110.

Tachikawa, Y. (2005). 若年層の携带メールにおける各種絵記号の使用-メールのテキスト分析 [The use of emoticons in mobile e-mail by youth: A text analysis of e-mail]. Gobun, 122, 108-123.

Takahashi, Y., Fukada, H., \& Akimitsu, K. (2006). Effect on the receiver's state-anxiety by the sender's use of emoticon, the receiver's sex, and the receiver's trait-anxiety under the condition of using a cellular phone mail . Hiroshima Psychological Research, 5, 93-107.

Tanaka, Y. (2001). 携帯電話と電子メイルの表現 [Expressions in mobile-phone and e-mail communication]. In 現代日本語講座 [Lectures on modern Japanese] (Vol. 2, pp. 98-127). Tokyo: Meiji Shoin.

The Agency for Cultural Affairs (2010). 改定常用漢字表 [Revised list of Chinese characters in common use]. Retrieved 5 August, 2017, from http://www.bunka.go.jp/bunkashingikai/soukai/pdf/kaitei_Kanji_toushin. pdf

Tochihara, N. (2010). 若年女性における携带メールの使い分け [Variations of mobile texting usage among young women]. Gobun, 137,111-101.

Uchida, Y. (2004). A study on "media-practice" of cell phone texting by youths: The influences of technical characteristics, "Double de-context nature". Studies in Ikuei Junior College, 21, 59-77.

Yamamoto, M., Ito, T., \& Taketsuna, S. (2008). 現代大学生の友人関係と携帯メールによるコミュニケー ション [Friendship and mobile phone e-mail by current university students]. Annual Report of Computer Center, Gakushuin University, 29, 27-34

Yamanishi, Y. (2007). Communication by written language among female university students: from the viewpoint of comparison of gender differences in media differences. Gobun, 128, 76-94.

Yasuhara, E., Ukimoto, E., Otsuka, M., Tomita, H., \& Choui, M. (2009). Communication using picture fonts in Keitai Email. Proceedings of symposium on mobile interactions 2009, 73-78.

\section{Notes}

Note 1. An important note here is that emoticons are not used in the same way by everyone. Sometimes recipients interpret them as having a different meaning from that which the original senders intended (Takahashi et al., 2005; Uchida, 2004).

Note 2. The small syllable pattern of りょうかい and the capitalization pattern of りようかい were not found in the collected data.

Note 3. "When expressing a single moji conversion to small moji, this paper describes it with ' $x$ ' before a target Romaji in considering the rule of typing by keyboard. For example, $\omega$ (small $\omega$ ) is described as 'xi'.

Note 4. The Emoji shown as examples are chosen for their readability when they are in the document and are therefore randomly selected from the three different carriers.

\section{Copyrights}

Copyright for this article is retained by the author(s), with first publication rights granted to the journal.

This is an open-access article distributed under the terms and conditions of the Creative Commons Attribution license (http://creativecommons.org/licenses/by/4.0/). 